\title{
Why Do Firms Hedge Selectively? Evidence from the Gold Mining Industry*
}

\author{
Tim R. Adam \\ School of Business and Economics \\ Humboldt University of Berlin \\ Spandauer Str. 1, 10178 Berlin, Germany \\ Tel.: +49 / 302093 5642; Fax: 49 / 3020935643 \\ E-mail:tadam@mit.edu \\ Chitru S. Fernando \\ Michael F. Price College of Business, University of Oklahoma \\ 307 West Brooks St., Norman, OK 73019, USA \\ Tel.: (405) 325-2906; Fax: (405) 325-7688 \\ E-mail: cfernando@ou.edu \\ Jesus M. Salas \\ Michael F. Price College of Business, University of Oklahoma \\ 307 West Brooks St., Norman, OK 73019, USA \\ Tel.: (405) 325-1135; Fax: (405) 325-7688 \\ E-mail: jsalas@ou.edu
}

\begin{abstract}
We examine why firms hedge selectively even though prior research shows that the gains from such speculative activities are economically insignificant. We find that smaller firms speculate more than larger firms, and that firms with a higher probability of bankruptcy speculate more than firms with a lower probability of bankruptcy. These cross-sectional differences are the opposite of what a theory of selective hedging based on information and financial superiority would predict, and are more consistent with an agency-theoretic or financial constraints explanation. We also find that selective hedging is negatively correlated with managerial stock and stock option holdings, which is inconsistent with the notion that convexity in managerial compensation is a motive for managers to speculate.
\end{abstract}

July 2008

JEL Classification: G11; G14; G32; G39

Keywords: Corporate risk management; selective hedging; speculation; managerial compensation; bankruptcy.

\footnotetext{
* We thank Alex Butler, Sudheer Chava, Sean Cleary, Louis Ederington, Gary Emery, Vladimir Gatchev, Janya Golubeva, Dirk Jenter, Leonid Kogan, Olaf Korn, Scott Linn, Gustavo Manso, Bill Megginson, Jun Pan, Roberto Rigobon, Antoinette Schoar, Pradeep Yadav and seminar participants at MIT, University of Oklahoma, University of Texas at Dallas, the 2007 European Finance Association Meeting, the 2007 FMA Annual Meeting and the 2007 FMA European Conference for their comments. We also thank Ted Reeve for providing us with his derivative surveys of gold mining firms, and Sridhar Gogineni and Leung Kam Ming for excellent research assistance. This research has been partially supported by the Research Grants Council of Hong Kong (Grant No. HKUST6138/02H). Fernando gratefully acknowledges financial support from the National Science Foundation (Grant No. ECS0323620) and Salas gratefully acknowledges financial support from the Center for Financial Studies, Michael F. Price College of Business. We are responsible for any remaining errors.
} 


\title{
Why Do Firms Hedge Selectively? Evidence from the Gold Mining Industry
}

\begin{abstract}
We examine why firms hedge selectively even though prior research shows that the gains from such speculative activities are economically insignificant. We find that smaller firms speculate more than larger firms, and that firms with a higher probability of bankruptcy speculate more than firms with a lower probability of bankruptcy. These cross-sectional differences are the opposite of what a theory of selective hedging based on information and financial superiority would predict, and are more consistent with an agency-theoretic or financial constraints explanation. We also find that selective hedging is negatively correlated with managerial stock and stock option holdings, which is inconsistent with the notion that convexity in managerial compensation is a motive for managers to speculate.
\end{abstract}


Recent studies of corporate risk management have documented a considerable divergence between the theory and practice of hedging. The existing theory of corporate risk management examines the conditions under which hedging increases firm value. ${ }^{1}$ However, recent evidence suggests that many firms also speculate with derivatives by varying the size and timing of their derivatives transactions based on their market views, a practice known as "selective hedging." Nonetheless, as noted by Stulz (1996), for selective hedging to be value increasing firms would need to possess private information about future market prices and the ability to act on this information without jeopardizing their core businesses. Whether this is indeed the case is uncertain. High profile derivatives-related losses at Proctor \& Gamble, Orange County, Amaranth Advisors and Asia Pulp \& Paper, for example, indicate that firms may erroneously believe that they possess valuable information when in fact they do not. Furthermore, Adam and Fernando (2006) report that for a sample of North American gold mining companies the cash flow gains from selective hedging were economically insignificant on average. Brown, Crabb and Haushalter (2006) also find little evidence of successful selective hedging.

The divergence between the theory and practice of hedging raises important concerns for shareholders and regulators alike, and generates interesting issues from an academic standpoint. The objective of our paper is to study selective hedging in the North American gold mining industry in order to understand what factors motivate managers to speculate in this way. The gold mining industry is a perfect laboratory for this study as it is, to our knowledge, the only

\footnotetext{
${ }^{1}$ See, for example, Stulz (1984), Smith and Stulz (1985), Stulz (1990), Froot, Scharfstein and Stein (1993), DeMarzo and Duffie (1995), and Mello and Parsons (2000) for further discussion on the theoretical motives for hedging.

${ }^{2}$ See, for example, Dolde (1993), Stulz (1996), Bodnar, Hayt and Marston (1998), Glaum (2002), Faulkender (2005), Adam and Fernando (2006), Brown, Crabb and Haushalter (2006), Beber and Fabbri (2006), Géczy, Minton and Schrand (2007), and Faulkender and Chernenko (2007).
} 
industry that makes sufficient detailed transaction-level data available to enable a systematic study of corporate speculation with derivatives within the context of a hedging program.

Stulz (1996) argues that firms may acquire private information through their regular business activities. For example, a large gas pipeline company or electricity transmission company might acquire valuable private information about market conditions and price trends through the operation of its network. In such cases, firms may be tempted to speculate in order to benefit from their proprietary information. However, selective hedging exposes a firm to considerably more risk than if it hedged without taking a market view because the firm's private information may be noisy or turn out to be irrelevant ex post. Stulz (1996) therefore predicts that only firms with sufficient financial strength will engage in selective hedging.

Stulz (1996) also notes that from an agency-theoretic standpoint, speculating could be a rational strategy for shareholders of firms in financial distress. Additionally, as argued by Campbell and Kracaw (1999), speculation may also be optimal for firms that have minimumscale projects and meager internal resources, and for which external financing is costly. Finally, Stulz (1996) argues that some incentive compensation schemes may induce managers to engage in selective hedging. For example, the value of stock options increases with the volatility of a firm's stock. Tufano (1996) shows that stock options reduce the likelihood that managers will hedge a firm's risk exposure, thereby increasing stock price volatility. It is possible that stock options may cause managers to become even more risk tolerant and engage in explicit market timing activities that further increase volatility and hence the value of their stock options.

Brown, Crabb and Haushalter (2006) examine how firm size, Altman's Z-score, insider ownership and managerial compensation are related to selective hedging in a sample of 44 gold producers, as part of their study of whether selective hedging results in economic gains for the 
firms that engage in it. While they do not report their results, they state that they find no significant relationship between selective hedging and any of these variables.

Géczy, Minton and Schrand (2007) provide a comprehensive study of the drivers of selective hedging. Using survey data from the Wharton Survey of Derivatives Usage (Bodnar, Hayt and Marston, 1998), they examine cross-sectional differences between firms that speculate and those that do not. They find that the sensitivity of CFO compensation to stock price movements (delta) is positively associated with the probability of actively taking positions, while the sensitivity of CEO compensation to stock price movements is negatively related to speculation. They argue that these findings are consistent with the CFO rather than the CEO being the active executive in determining day-to-day derivatives transactions. Beber and Fabbri (2006) also examine the link between CEO compensation and selective hedging for a sample of large U.S. non-financial firms with foreign currency exposure. They document a weakly significant positive relation between CEO delta and selective hedging, although they also show that managers whose compensation is tied to stock return volatility will hedge less.

While providing important new insights, the studies by Géczy, Minton and Schrand (2007) and Beber and Fabbri (2006) have significant data limitations. First, unlike our data set from the gold mining industry, neither study utilizes a data set that permits the authors to undertake an in-depth examination of selective hedging at the level of individual derivatives transactions. Additionally, the data sets utilized by Géczy, Minton and Schrand (2007) and Beber and Fabbri (2006) do not have a level of detail sufficient to determine whether or not selective hedging is successful in their respective samples and thereby provide a context for what may motivate firms to hedge selectively. The evidence documented by Adam and Fernando (2006) and Brown, Crabb and Haushalter (2006) clearly shows that selective hedging gains in the gold 
mining industry are not economically significant. Finally, both Géczy, Minton and Schrand (2007) and Beber and Fabbri (2006) examine selective hedging in foreign currency markets where even large corporations are unlikely to have information advantages. In contrast, the gold mining industry is a more specialized commodity industry and it is easier to conceive of the possibility that some firms in this industry have a comparative advantage in predicting future gold price trends. ${ }^{3}$

We find a negative relationship between selective hedging and firm size. If firm size is a proxy for proprietary information in the gold market then this result is the opposite to what one would expect under a rational, value-maximizing model of corporate behavior. Graham and Harvey (2001) note that smaller firms are financially less sophisticated than larger firms. Thus, smaller firms may be more likely to erroneously believe that they have an information advantage. It is also possible that smaller firms are more constrained in raising external capital due to asymmetric information, and engage in selective hedging to supplement their smaller internal resources, as predicted by Campbell and Kracaw (1999).

Furthermore, we find that firms that are closer to financial distress, as measured by Altman's Z-score, also speculate more. This result supports the agency-theoretic notion articulated by Stulz (1996) that shareholders of firms that are closer to bankruptcy have incentives to speculate at the expense of bondholders. This finding is also consistent with the argument in Campbell and Kracaw (1999) that more financially constrained firms have stronger incentives to speculate.

\footnotetext{
${ }^{3}$ Indeed, Brown, Crabb and Haushalter (2006) provide anecdotal evidence that markets react significantly to hedging announcements by some gold producers, which is consistent with the possibility that these firms may have superior information about the gold market. Nonetheless, Brown, Crabb and Haushalter (2006) also conclude that on average, market timing by gold producers does not create substantial shareholder benefits.
} 
Given the findings in Adam and Fernando (2006) and Brown, Crabb and Haushalter (2006) that speculation does not create value for shareholders, we would expect managers who act in the interest of shareholders to refrain from speculation. This is what we find for incentive compensation. In particular, we find no evidence that convexity in managerial compensation packages provides managers with incentives to speculate. In fact, our findings support the opposite view, that stock and stock option compensation are more likely to mitigate a manager's incentive to hedge selectively, thus confirming the traditional view that stock-based compensation aligns the incentives between managers and shareholders. Our results are in stark contrast to recent findings by Burns and Kedia (2006) and Denis, Hanouna and Sarin (2006) that stock option compensation is positively related to the likelihood that managers will engage in behaviors that destroy shareholder value. ${ }^{4}$ Finally, we also find that insider ownership is weakly negatively correlated with the extent of selective hedging. Given that selective hedging does not appear to add value, this finding suggests that larger ownership stakes by insiders may also deter managers from speculating.

Our findings are considerably stronger and less ambiguous than the results in the three prior studies that have examined the determinants of selective hedging. In contrast to Brown, Crabb and Haushalter (2006) who find no significant relationships between selective hedging and firm size, Altman's Z-score, or managerial compensation in their study of gold producers, we find strong and consistent results for all these relationships. The stark difference between our findings and their findings can be attributed to the considerably smaller sample utilized by Brown, Crabb and Haushalter (2006). While our finding of a negative relation between

\footnotetext{
${ }^{4}$ Burns and Kedia (2006) find that the sensitivity of the CEO's option portfolio to stock price is significantly positively related to the propensity to misreport earnings. Denis, Hanouna and Sarin (2006) find that stock options increase the incentive for managers to engage in fraudulent activity.
} 
speculation and CEO compensation delta is consistent with the finding in Géczy, Minton and Schrand (2007) (and the opposite of the finding in Beber and Fabbri (2006)), our finding for CFO compensation delta, which is also negatively related to speculation in our study, is the opposite of what Géczy, Minton and Schrand (2007) find. Overall, our findings for both CEO and CFO compensation, measured in terms of both delta and vega, paint a consistent picture of a negative relation between speculation and incentive compensation.

The rest of our paper is organized as follows. In Section I we briefly review the existing evidence on selective hedging and formulate our empirical hypotheses. Section II describes our data set. Section III examines the relationships between selective hedging, firm size and other firm characteristics. Section IV analyzes the relationship between selective hedging and managerial compensation. Section V presents additional robustness checks of our findings and Section VI concludes.

\section{Empirical Hypotheses}

The traditional theory of corporate risk management assumes that firms use derivatives purely for hedging purposes and that the benefits of hedging accrue solely from the alleviation of market imperfections. In contrast, there is now considerable survey evidence that managers also speculate with derivatives, i.e., incorporate their market views into their hedging programs. In a survey of 244 Fortune 500 firms, Dolde (1993) reports that almost 90\% of firms at least sometimes base the size of their hedges on their views of future market movements. Bodnar, Hayt and Marston (1998) survey derivatives policies by 399 U.S. non-financial firms and find that about $50 \%$ of their sample firms admit to sometimes (and 10\% frequently) altering the size and/or the timing of a hedge based on their market views. Glaum (2002) surveys the risk 
management practices of the major non-financial firms in Germany. He finds that the majority follows forecast-based, profit-oriented risk management strategies. Faulkender (2005) examines whether firms are hedging or timing the market when selecting the interest rate exposures of their new debt issuances. He finds that the interest rate exposure chosen is a function of the slope of the yield curve. Faulkender and Chernenko (2007) further explore the reasons for the interest rate timing behavior documented by Faulkender (2005). Their empirical findings suggest that the choice of interest rate exposure is primarily driven by a desire to meet consensus earnings forecasts and to raise managerial pay. Adam and Fernando (2006) find considerable evidence of selective hedging in their sample of gold mining firms but find no economically significant cash flow gains on average from selective hedging. Brown, Crabb, and Haushalter (2006) also study selective hedging in the gold mining industry and arrive at a similar conclusion. Beber and Fabbri (2006) analyze the time-series variation of foreign currency derivatives in a sample of large U.S. non-financial firms and document a substantial time-series variation in currency derivatives holdings in excess of what can be explained by changes in currency exposure, which they attribute to selective hedging.

Collectively, these studies suggest that the practice of selective hedging is widespread in the corporate world. In the next subsection we develop a series of hypotheses to guide our empirical analysis of selective hedging and help understand why firms engage in this practice.

\section{A. Empirical Hypotheses}

Stulz (1996) argues that some firms may incorporate their market views into their hedging programs if they possess valuable private market information. He cites as an example a large copper consuming firm, which obtains access to private information about the copper 
market as a result of its copper purchasing activities. Another example might be a large gas transmission and distribution company, which acquires valuable information about gas demand and supply through the operation of its gas pipeline network. The extent of private information a firm acquires is, of course, unobservable. However, as in the above examples, a firm's access to valuable private information is likely to increase with its presence in the market and the resources it can expend to gather such information, both of which can be proxied by the size of the firm (Brown, Crabb and Haushalter (2006)). Therefore, we can state our first empirical hypothesis as follows:

Hypothesis 1: Larger firms speculate more than smaller firms.

The second criterion stipulated by Stulz (1996) for successful value-maximizing speculation is that firms have the financial strength to bear the additional risk of acting on their market views without jeopardizing their core businesses. This gives rise to our second empirical hypothesis:

Hypothesis 2: Financially stronger firms speculate more than financially weaker firms.

Wealth transfer motives as in Jensen and Meckling (1976) and Myers (1977) would provide managers of financially distressed firms with an incentive to speculate regardless of whether or not they have an information advantage. Campbell and Kracaw (1999) argue that financially constrained firms may also have incentives to speculate to supplement their internal 
cash reserves and thereby overcome the constraints of accessing external capital markets. If speculation in our sample of firms is driven by such motives, we expect to find that:

Hypothesis 3: Financially constrained or distressed firms speculate more than unconstrained firms.

It is important to note that Hypotheses 2 and 3 make opposing predictions.

If managers act in their self-interest then selective hedging may also be driven by managerial incentives. For example, the value of stock options increases with the volatility of the underlying stock. To the extent that selective hedging increases the volatility of a firm's equity, managers that hold significant stock option portfolios may be more inclined to speculate than managers with few or no stock options. We therefore expect to find a positive relationship between speculation and the sensitivity of executives' compensation packages to their firm's stock price volatility.

Hypothesis 4: Corporate speculation increases with the sensitivity of managerial stock option holdings to the volatility of a firm's stock price.

The findings by Adam and Fernando (2006) and Brown, Crabb and Haushalter (2006), that firms do not earn significantly positive cash flows on average from selective hedging, imply that corporate speculation is value-destroying or, at best, value-neutral. If this is common knowledge among a firm's managers and other insiders, we would expect that managers who receive higher equity-based compensation will speculate less. 
Hypothesis 5: Corporate speculation decreases with the sensitivity of managerial stock and stock option holdings to the firm's stock price.

\section{Data and Methodology}

We study the derivatives transactions of a sample of 92 North American gold mining firms. The derivatives data is from the Gold and Silver Hedge Outlook, a quarterly survey conducted by Ted Reeve, an analyst at Scotia McLeod, from 1989 to 1999. The firms included in the survey represent the majority of firms in the gold mining industry during this period. Firms that are not included tend to be small or privately held corporations.

The Scotia McLeod survey contains detailed information on all outstanding gold derivatives positions, i.e., the type of instrument, the size and direction of the position, average delivery prices and maturities for each instrument type, and the future expected gold production. There are a total of 2,541 firm-quarter observations of which 1,450 firm-quarters represent nonzero hedging portfolios. Tufano (1996) and Adam and Fernando (2006) provide further details about this data set.

We obtain financial data from Compustat or from a manual search of firms' financial statements if a firm is not covered by Compustat. Stock market return data comes from the CRSP database and Datastream. Operational data, e.g., gold production figures, gold reserves, etc., is collected manually from firms' financial statements.

Following Tufano (1996), we measure the extent of derivatives usage by a hedge ratio that is defined as follows:

$$
\text { Total hedge ratio }=\frac{- \text { Portfolio delta }(1-3 \text { year contracts })}{\text { Expected production }(1-3 \text { years ahead })}
$$


As noted by Tufano (1996), the portfolio delta is the amount of gold that the firm has effectively sold short, computed as the sum of the firm's individual derivatives positions (in ounces of gold) weighted by their respective deltas. The total hedge ratio is the fraction of the firm's expected gold production over the next three years that it has hedged, calculated as the ratio of the portfolio delta for derivatives contracts that mature within three years to expected production (in ounces of gold) over the same time period. ${ }^{5}$ We also measure the extent of derivatives usage for each hedge horizon individually, to check the robustness of our results using the total hedge ratio and to determine the extent to which any selective hedging patterns we observe at the aggregate level over the three-year window persist in individual contract maturity years:

$$
x-\text { year hedge ratio }=\frac{- \text { Portfolio delta }(x-\text { year contracts })}{\text { Expected production }(x \text { years ahead })}
$$

The $x$-year hedge ratio represents the fraction of the gold production $x$ years ahead that has been hedged.

The above hedge ratios have a quarterly data frequency, which allows us to measure the extent to which a firm speculates by the standard deviation of the hedge ratios. More specifically, for a given firm-year observation, the extent of speculation is the standard deviation of the

\footnotetext{
${ }^{5}$ The survey reports derivatives contracts with maturities of up to five years. However, since only a few firms use four and five year hedges - the average contract maturity is 1.5 years - we focus our attention on derivatives contracts that mature within three years. Including four and five year maturities does not change any of our conclusions. The results are available from the authors upon request. In Section V, we carry out additional robustness checks using two alternate measures of the total hedge ratio in which the denominator in expression (1) is replaced by the firm's gold reserves as in Jin and Jorion (2006), and the numerator is replaced by (1-3 year) portfolio delta and (1-5 year) portfolio delta, respectively.
} 
quarterly hedge ratios in that year. ${ }^{6}$ We refer to speculation measured using the standard deviation of the total hedge ratio as "total speculation" and speculation measured using the standard deviation of the $x$-year hedge ratio as " $x$-year speculation."

We gather compensation data through ExecuComp or through manual collection from proxy statements if the firm is not covered by ExecuComp. We then calculate the stock and option holdings for CEOs and CFOs and aggregate stock holdings for all insiders (executives and members of the board of directors). In addition, we estimate the sensitivities of stock and option holdings to changes in stock price level (delta) and volatility (vega) following the methodology of Core and Guay (2002). We use the end of year stock price from Compustat as the underlying stock price in the Black-Scholes options pricing formula. We obtain any cash dividends paid by the firm from Compustat. The risk-free interest rate is the yield on the Treasury bond whose maturity is closest to the maturity of the stock option. We compute stock return volatility from weekly adjusted stock returns obtained from CRSP and Datastream. We calculate the delta of each executive's compensation as the sum of the deltas of all outstanding options plus the delta of the executive's shareholdings. We calculate the vega of the executive's compensation as the sum of the vegas of all option holdings of the executive. Following Coles, Daniel and Naveen (2006), we assume the vega of shareholdings to be zero. The Appendix provides further details on the calculation of delta and vega. For speculation in year $t$ we use compensation data from proxies issued in year $t$, which correspond to compensation data in year $t-1$. Table 1 provides

\footnotetext{
${ }^{6}$ Brown, Crabb and Haushalter (2006) also use the standard deviation of quarterly hedge ratios to measure the extent of speculation, while Beber and Fabbri (2006) use the standard deviation of foreign currency derivatives holdings. Adam and Fernando (2006) use five different methods to measure the deviation of actual hedge ratios from "predicted" hedge ratios, i.e., hedge ratios attributable to pure hedging. One of these methods is the deviation of quarterly hedge ratios from the firm's average quarterly hedge ratio, which corresponds to the approach we employ here and used in Brown, Crabb and Haushalter (2006). Adam and Fernando (2006) conclude that the five methods yield broadly similar results, which lends support to the use of quarterly hedge ratio standard deviation as our measure of speculation. Nonetheless, Adam and Fernando (2006) also note that none of these measures are likely to be able to precisely measure selective hedging.
} 
summary statistics of our sample.

[Place Table 1 about here]

We measure the probability of bankruptcy by Altman's Z-score (see Appendix). Altman (1968) shows that firms with Z-scores less than 1.81 are associated with a high probability of distress, whereas firms with Z-scores above 2.99 are in the "safe zone." While the mean and median Z-scores in our sample are 2.548 and 2.471 , respectively, the $25^{\text {th }}$ and $75^{\text {th }}$ percentiles are 0.918 and $4.819 .{ }^{7}$ Thus, despite the industry focus the firms in our sample exhibit a wide range of probabilities of bankruptcy with approximately a third facing a high probability of financial distress based on Altman (1968).

Firms hedge an average of $20 \%$ of their expected gold production over a three-year period. Average hedge ratios decline from $35 \%$ for one-year maturities to $9 \%$ for three-year maturities, indicating that most of the derivatives activity takes place in shorter maturity contracts. We observe a corresponding trend in our speculation measures as the contract maturity period increases.

We test our empirical hypotheses in Sections III and IV by examining how speculation by firms in our sample is related to firm size, probability of bankruptcy as measured by Altman's Z score, and measures of CEO and CFO compensation. We first test all our hypotheses using OLS regressions for the sample of firms that uses derivatives. Since the decision to use derivatives is not random, it is possible that our selective hedging sample may be subject to sample selection bias. Therefore, we repeat all the tests of our empirical hypotheses using the Heckman (1979) two-step selection model. We model the decision to use derivatives in the first step using a probit model. We employ as our dependent variable a hedging dummy indicating whether or not the

\footnotetext{
${ }^{7}$ We winsorize the Z-scores at zero on the left and five on the right to prevent our results from being influenced by extreme values.
} 
firm uses derivatives, and several independent variables that have been identified in the prior literature as determinants of hedging. These variables include firm size, the market-to-book ratio of assets, dividend policy, liquidity and leverage. ${ }^{8}$ We model speculation in the second step using OLS, with our speculation measure as the dependent variable. Our independent variables are the determinants of speculation based on our empirical hypotheses together with the Inverse Mills Ratio from the first step to correct for any sample selection bias. We conduct our analysis using the total measures of hedging and speculation based on all derivatives outstanding up to three years in maturity as well as the disaggregate measures pertaining to individual maturity years $(1$, 2, or 3 years). We present the results of further robustness checks in Section V.

\section{Selective Hedging and Firm Characteristics}

In this section, we examine how selective hedging is related to firm size and the probability of bankruptcy. We first present our regression results using OLS, followed by the Heckman (1979) two-step selection model regression results correcting for any sample selection bias.

\section{A. Speculation, Firm Size and Probability of Bankruptcy}

We first examine the relationships between speculation and firm size, and between speculation and the probability of bankruptcy. In Table 2 we present the results of our OLS regressions for the sample of firms that uses derivatives. We control for firm-level clustering in all our tests to avoid biased standard errors (Petersen (2008)).

[Place Table 2 about here]

\footnotetext{
${ }^{8}$ See, for example, Tufano (1996), Mian (1996) and Haushalter (2000).
} 
Our OLS regression results provide strong evidence that smaller firms speculate more than larger firms for all hedging maturities and in aggregate. The relationship between speculation and size is negative and significant at the $1 \%$ level for total speculation and for one and two-year speculation. This result contrasts sharply with the finding in the literature that larger firms hedge more than smaller firms. ${ }^{9}$ We also find a strong negative relationship between speculation and Z-score, which is significant at the $1 \%$ level for total speculation and two-year speculation, and at the 5\% and 10\% levels for one-year and three-year speculation, respectively.

As noted in Section $\mathrm{I}$, the theoretical relation between selective hedging and the likelihood of financial distress is ambiguous. On the one hand, Stulz (1996) highlights the need for firms that engage in selective hedging to have the financial strength to bear the additional risk of acting on their market views. On the other hand, Stulz (1996) and Campbell and Kracaw (1999) provide different reasons as to why financially distressed firms could have more incentives to speculate than financially secure firms. To test for this potential convexity, we allow for the relationship between speculation and Z-scores to be non-linear by including the square of Z-scores. Interestingly, we find a weak quadratic relationship between Z-scores and selective hedging, with the coefficient on the $Z^{2}$ term being positive and significant at the $5 \%$ level for total speculation and for 3-year speculation.

We use the Heckman (1979) two-step procedure to ensure the robustness of our OLS results. We first model the likelihood that a firm hedges in a given quarter and then, in the second step, model the magnitude of speculation as measured by the volatility of hedge ratios (given that a firm chooses to hedge). Thus, the sample in the second step is limited to hedgers.

\footnotetext{
${ }^{9}$ See, for example, Tufano (1996), Mian (1996), Bodnar, Hayt and Marston (1998), Haushalter (2000) and Adam and Fernando (2006). The positive relation between hedging and size is also confirmed in our Heckman (1979) twostep regression presented in Table 3 (Panel A).
} 
The first step results are presented in Panel A of Table 3. The dependent variable in the first step is a hedging dummy that equals one if the firm has derivatives outstanding with maturities of up to 3 years, and zero otherwise (models I to III). To check robustness we also consider dummy variables for each hedging maturity (1, 2 or 3 years) separately (models IV to XII). We observe a strong positive relationship between the likelihood of using derivatives and firm size, which is consistent with the prior literature listed in footnote 9. We find consistent results across the different regression models, which include total hedging dummies measured by aggregating across the three years, and hedging dummies within individual maturity years. The negative relation between the market-to-book ratio and the decision to use derivatives is consistent with the evidence of Mian (1996). We attribute this negative relation to the fact that in our sample the market-to-book ratio, as a proxy for growth opportunities, is negatively correlated with firm size, and smaller firms are less likely to use derivatives. Holding liquidity can be seen as a substitute for hedging, which would explain the negative correlation between the decision to use derivatives and the quick ratio. Overall, these results are consistent with Tufano (1996) and Adam (2002).

\section{[Place Table 3 about here]}

Panel B of Table 3 presents the results from the second step of the Heckman (1979) selection model on the question of how the degree of speculation is related to firm characteristics. Specifically, we examine how firm size, as a proxy for inside information about the gold market, and Altman's Z-score, as a measure of the probability of bankruptcy, are related to the extent of speculation. As previously discussed, our measure of the extent of speculation is the standard deviation of the quarterly hedge ratios, both in total and by maturity. The total hedge ratio is the proportion of the expected production in the next three years that is hedged. 
Surprisingly, the results in Panel B of Table 3 show that larger firms speculate less than smaller firms for all hedge maturities and in total, confirming our findings in the OLS regressions. In particular, an increase in a firm's market value by one standard deviation from the mean is associated with a decrease in total speculation by around 0.037 . Given that the mean value of total speculation is only 0.0771 , this represents a reduction of $48 \%$. This finding stands in stark contrast to our finding in Panel A that larger firms are more likely to hedge than smaller firms. The Inverse Mills ratio is statistically significant in some of the regressions, validating our use of the Heckman (1979) two-step procedure to correct for any sample selection bias.

As previously discussed, we use Altman's Z-score as a measure of the firm's likelihood of bankruptcy, where higher Z-scores are associated with a lower chance of bankruptcy. Examining the coefficients on Z-score alone in Panel B of Table 3, we find a statistically significant negative correlation between speculation and Z-score, again confirming the findings in our OLS regressions. The correlation between total speculation and the Z-score is significant at the $5 \%$ and $1 \%$ levels in the respective models, while the results for individual maturities are somewhat weaker although of consistent sign. In particular, an increase in the Z-score by one standard deviation is associated with a decrease in total speculation by 0.0185 , which represents a reduction of $24 \%$. This result supports the arguments in Stulz (1996) and Campbell and Kracaw (1999) that financially weaker firms will speculate more.

When we test for the potential convexity in the relationship between speculation and Zscore that was documented in the OLS regressions, we continue to find the previous quadratic relationship, with the coefficient on the $\mathrm{Z}^{2}$ term being positive and statistically significant at the $1 \%$ level for total speculation and for 3-year speculation. A closer examination of the data reveals that this relationship is driven by firms increasing their selective hedging activity at an 
accelerating rate as they get closer to bankruptcy rather than by a U-shaped pattern between selective hedging and the probability of bankruptcy. Therefore, we can rule out the possibility that financially stronger firms also speculate more. We should also note that the previously observed relationship between speculation and size remains generally robust when we control for the likelihood of bankruptcy.

\section{B. Discussion}

We find that larger firms are more likely to hedge than smaller firms. These findings are consistent with prior studies, and may indicate that larger firms are more sophisticated and can commit greater financial resources and expertise to a risk management program than smaller firms. In contrast, we find that smaller firms speculate more than larger firms when they do use derivatives. This finding is puzzling because larger firms are more likely to have an information advantage about the gold market than smaller firms and therefore, if firms speculate based on superior information, we would expect to see a higher propensity among larger firms to engage in selective hedging. It is possible that smaller firms are more likely to erroneously believe that they have information the market does not have, when in fact they do not, which is consistent with the finding in Adam and Fernando (2006) that firms do not generate economically significant cash flows on average from selective hedging. This finding is also consistent with the view stemming from Graham and Harvey (2001) that smaller firms are financially less sophisticated than larger firms.

Our findings are also consistent with the argument in Campbell and Kracaw (1999). Smaller firms are more constrained in raising external capital due to asymmetric information, and may engage in selective hedging in the hope of supplementing their smaller internal 
resources. Additionally, our finding that firms that have a higher probability of bankruptcy speculate more lends support to the agency-theoretic notion (Jensen and Meckling, 1976) that shareholders of firms close to bankruptcy may have incentives to speculate at the cost of bondholders.

\section{Managerial Compensation and Selective Hedging}

We now turn to our managerial compensation hypothesis, which is based on the notion that managers speculate as a rational response to incentive compensation. As noted in Section I, our hypotheses are conditioned on the findings in Adam and Fernando (2006) and Brown, Crabb and Haushalter (2006) that selective hedging does not create value for shareholders.

\section{A. Speculation and Executive Compensation}

Given that selective hedging does not increase firm value on average and that managers are presumably aware of this fact, we expect that managerial ownership of the firm through incentive compensation would attenuate a manager's incentive to speculate. Ownership can be obtained through holding stock as well as stock options, which we measure by the sum of the deltas of stock and stock option holdings of the CEO or the CFO. The value of executive stock options, however, increases with stock price volatility. Thus, stock options could induce a manager to increase the volatility of the stock by speculating. We measure the sensitivity of stock option holdings to changes in the stock price volatility by calculating the aggregate vega of the option holdings of the CEO or CFO.

We present our findings from our OLS (univariate) regressions pertaining to CEO and CFO compensation in Table 4. Panel A provides the results for CEOs and Panel B provides the 
results for CFOs. Speculation is weakly negatively related to CEO delta, with the coefficient for one-year speculation being statistically significant at the $5 \%$ level while the coefficient for twoyear speculation is significant at the $10 \%$ level. CEO vega is also negatively related to speculation, with the coefficient for total speculation being significant at the $5 \%$ level and the coefficient for one-year speculation being significant at the $10 \%$ level. For CFOs, the negative relation between speculation and delta is stronger, with the coefficients for one and two-year speculation being significant at the $1 \%$ level while the coefficient for total speculation is significant at the $5 \%$ level. CFO vega is also negatively related to speculation, with the coefficient for total speculation being significant at the $5 \%$ level while the coefficient for oneyear speculation is significant at the $1 \%$ level. Overall, our OLS results contradict the notion that incentive compensation exacerbates the incentive for executives to engage in speculation for private benefit, suggesting instead that executive compensation diminishes the incentives for executives to engage in speculation.

[Place Table 4 about here]

As in the previous section, we estimate Heckman (1979) selection models to ascertain the robustness of our OLS regression results, with the decision to hedge being modeled in the first step as previously ${ }^{10}$ and the extent of selective hedging being modeled in the second step. Our results are broadly consistent with our OLS regression findings. The results for CEO compensation are presented in Table 5. CEO delta is negatively related to speculation, which is statistically significant at the $1 \%$ level for two-year speculation and at the $5 \%$ level for total and one-year speculation. After controlling for firm size, we find that the negative relationship persists but weakens considerably, with only the coefficient for two-year speculation remaining

\footnotetext{
${ }^{10} \mathrm{We}$ omit reporting the first-step results in the rest of the paper since they are essentially identical to those in Table 3. They are available from the authors upon request.
} 
significant (at the 5\% level). Our result for CEO delta is consistent with the finding of Géczy, Minton and Schrand (2007). CEO vega is also negatively related to speculation, which is statistically significant at the $1 \%$ level for total and two-year speculation, and at the $5 \%$ level for one-year speculation. The negative relationship persists when firm size is controlled for, with both the total and two-year speculation coefficients remaining significant at the $5 \%$ level.

[Place Table 5 about here]

Our results for CFO compensation presented in Table 6 are consistent with our previous OLS regression findings. While our findings for CFOs are also consistent with the negative speculation-compensation relationship we documented for CEOs, it is statistically stronger. The relationship between CFO delta and speculation is negative and statistically significant for total, one and two-year speculation, regardless of whether or not we control for firm size. The relationship between CFO vega and speculation is negative and statistically significant for total and one-year speculation, regardless of whether or not we control for firm size. Our finding for CFO delta is the opposite of what Géczy, Minton and Schrand (2007) report for their sample of firms.

[Place Table 6 about here]

Taken together, our findings contradict the notion that stock option ownership induces executives to speculate in order to increase volatility. Consistently, both CEO and CFO stock ownership (delta) are negatively correlated with selective hedging, which suggests that stock ownership also reduces the incentives for executives to engage in speculation. 


\section{B. Discussion}

Our findings on the relationship between speculation and managerial incentives provide no support for (and indeed, contradict) the notion that managers speculate in their own self interest. Our finding that speculation decreases with the vega of option holdings by both CEOs and CFOs directly contradicts the view that stock option ownership could motivate managers to speculate in order to increase stock return volatility and thus the value of their stock options. Our finding that speculation decreases with the delta of managerial stock and option ownership suggests that rewarding managers through stock and options may actually reduce their incentives to speculate.

Our overall finding, that stock or option compensation reduces the incentive for managers to speculate, confirms the traditional view that equity-linked compensation aligns the incentives between managers and shareholders and runs counter to the findings in recent studies by Burns and Kedia (2006) and Denis, Hanouna and Sarin (2006) that stock option compensation is positively related to the likelihood that managers will engage in strategies that potentially hurt shareholders. Burns and Kedia (2006) find that the sensitivity of the CEO's option portfolio to stock price is significantly positively related to the propensity to misreport earnings, while Denis, Hanouna and Sarin (2006) find that stock options increase the incentive for managers to engage in fraudulent activity. It is possible that their awareness that selective hedging does not create value, coupled with their own stakes in the firm, deter executives who own options and stock from engaging in speculation. 


\section{Additional Robustness Checks}

In this section, we further examine the robustness of the findings presented in the previous two sections by performing additional tests. We first carry out robustness checks using two alternate measures of the total hedge ratio in which Expected production (1-3 years ahead) in the denominator of expression (1) for the total hedge ratio is replaced by the firm's gold reserves, as in Jin and Jorion (2006). In the first alternate measure of the total hedge ratio, the numerator remains the same as in (1), i.e., is set equal to - Portfolio delta (1-3 year contracts). In the second alternate measure of the total hedge ratio, we extend the hedging horizon to the full five year window for which data is available, and set the numerator equal to - Portfolio delta (15 year contracts). Using these alternate measures of the total hedge ratio, we repeat the aggregate analysis (only) presented in Tables 2 through 6. As before, speculation is measured by the standard deviation of the hedge ratio.

The results of the OLS regression analysis are presented in Table 7. Regardless of which measure of total speculation we use, the results are consistent with our previous findings, with speculation being significantly negatively related to firm size and $\mathrm{Z}$ score, significantly positively related to $\mathrm{Z}^{2}$, and significantly negatively related to $\mathrm{CEO} / \mathrm{CFO}$ delta and vega.

[Place Table 7 about here]

As before, we repeat the analysis using the Heckman (1979) two-step procedure and present the second step results in Table 8. Panel A reports the results of the alternate total speculation measure using - Portfolio delta (1-3 year contracts) (“Total Speculation R1") in the numerator while Panel B reports the results of the alternate total speculation measure using Portfolio delta (1-5 year contracts) (“Total Speculation R2”) in the numerator. The results are broadly consistent with our previous OLS regression results and the findings reported in Tables 2 
to 6, although they are somewhat weaker statistically. In both panels, firm size and $\mathrm{Z}$ score continue to be negatively related to speculation. However, $\mathrm{Z}^{2}$ is statistically significant only in Panel B. In the univariate models, CEO/CFO delta and vega are all significantly negatively related to speculation in Panel A, while only CEO delta and vega are significant in Panel B. However, only vega of CEO compensation in Panel A remains significant when firm size is controlled for. The reduction in statistical significance may be due in part to the increased noise associated with using reserves in the denominator instead of production over the specific period that corresponds to the computation of portfolio delta in the numerator.

[Place Table 8 about here]

As a final robustness check, we examine the relation between selective hedging activity and insider ownership. Since selective hedging does not create value for shareholders, we would expect to find a negative relation between selective hedging activity and insider ownership, which would not only be consistent with our previous results on managerial compensation but also with the view that a larger ownership stake by insiders would help dissuade managers from engaging in activity that does not create value for shareholders. We present the findings from our OLS regressions in Table 9. We use both our original measure of total speculation and the two robustness measures introduced in this section, together with individual year speculation measures as before. We find a significant negative relationship between insider ownership and speculation for two of our three total speculation measures and for our one and two-year speculation measures. This finding suggests that larger ownership stakes by insiders will attenuate the incentive for managers to engage in speculation.

[Place Table 9 about here] 
We present the corresponding Heckman (1979) two-step regression analysis in Table 10. In the univariate models, speculation is significantly negatively related to insider ownership for two of our three total speculation measures and for our one-year speculation measure. However, the relationship loses significance when we control for size.

[Place Table 10 about here]

\section{Conclusions}

There is considerable evidence that firms use derivatives not only to hedge but also to speculate, even though the gains from speculation appear to be small at best. This raises the question of why managers commit time and resources to an activity that does not appear to increase shareholder value. We examine this puzzle by studying derivatives strategies of firms in the North American gold mining industry. This industry likely satisfies the conditions stipulated by Stulz (1996) for rational (shareholder value-maximizing) speculation. However, we find that small firms are more active speculators than large firms. This is surprising because small firms should be less likely than large firms to have an information advantage and thus be able to beat the market. Furthermore, small firms should be less able to bear the additional risks of selective hedging than large firms. We find that the extent of selective hedging increases as the probability of bankruptcy rises, which is consistent with an agency-theoretic or financial constraints explanation of corporate speculation. Our findings on the relationship between speculation and managerial incentives provide no support for (and indeed, contradict) the possibility that managers may be speculating in their own self interest. We find that rewarding managers through stock and stock options may actually reduce their incentives to speculate. 
Given that selective hedging does not benefit shareholders, our study renews the challenge of explaining this behavior from a rational value-maximizing standpoint. In addition to the possibility that the speculation undertaken by financially distressed firms may be driven by wealth transfer or financial constraints motives, our results also point to the remaining possibility for selective hedging highlighted by Stulz (1996) -- that managers hedge selectively because they erroneously believe that they can outperform the market. This conclusion raises many new questions that have relevance for both academics and practitioners, especially from the standpoint of corporate governance and behavioral finance. 


\section{Appendix : Definition of Variables}

This Appendix lists all the variables used in the paper, provides their definitions and explains how they are constructed. In addition to the 1989 to 1999 gold derivatives data set from the Gold and Silver Hedge Outlook by Ted Reeve/Scotia McLeod, the principal data sources are Compustat, CRSP, ExecuComp, firms' annual reports and 10-K forms. Market data is obtained from Datastream.

CEO/CFO compensation delta and vega: $\mathrm{CEO} / \mathrm{CFO}$ (aggregate) compensation delta is the change in the dollar value of the executive's wealth derived from ownership of stock and stock options in the firm when the firm's stock price changes by one percent. CEO/CFO (aggregate) compensation vega is the change in the dollar value of the executive's wealth derived from ownership of stock and stock options in the firm when the annualized standard deviation of the firm's stock price changes by 0.01 . We calculate the (aggregate) delta of the executive's compensation as the sum of the deltas of the options holdings and the delta of the stock holdings. We obtain the (aggregate) vega of the executive's compensation as the sum of the vegas of the executive's options holdings. Following Coles, Daniel and Naveen (2006) we disregard the vega of stock holdings. The delta and vega of options holdings are calculated based on the methodology in Guay (1999) and Core and Guay (2002). ${ }^{11}$

The deltas of stock and options holdings are given by:

$$
\begin{gathered}
\text { Delta (stock holdings) }=0.01 * S * \text { number of shares owned } \\
\text { Delta (options holdings) }=0.01 * e^{-d T} N(Z) S * \text { number of options owned }
\end{gathered}
$$

where $Z=\left(\ln (S / X)+T\left(r-d+\sigma^{2} / 2\right)\right) /\left(\sigma T^{0.5}\right)$

$S=$ underlying stock price

$X=$ option exercise price

$T=$ time to maturity of the option (number of years)

$r=\ln [1+$ risk-free interest rate $]$

\footnotetext{
${ }^{11}$ Following the convention in previous studies, while all the delta and vega measures we use in our analysis are aggregates over the executive's entire holdings in the firm, we omit using the qualifier "aggregate" when referring to compensation deltas and vegas elsewhere in the paper.
} 
$d=\ln [1+$ expected dividend rate on the stock $]$

$\sigma=$ annualized stock return volatility

$N=$ cumulative density function for normal distribution

The vega of options holdings is given by:

$$
\text { Vega (options holdings) }=0.01 * e^{-d T} N^{\prime}(Z) S T^{0.5} * \text { number of options owned }
$$

where $N=$ probability density function for normal distribution

Dividend dummy: Equals one if a firm paid cash dividends in the given year and is zero otherwise.

Firm size: The natural log of the market value of assets. The market value of assets equals book value of assets minus book value of common stock plus market value of equity.

Portfolio Delta: Portfolio delta is the amount of gold that the firm has effectively sold short over a specific time period, computed as the sum of the firm's individual derivatives positions (in ounces of gold) weighted by their respective deltas.

Hedge ratio: The total hedge ratio is the fraction of the firm's expected gold production over the next three years that it has hedged, calculated as the ratio of the portfolio delta for derivatives contracts that mature within three years to expected production (in ounces of gold) over the same three-year time period. Correspondingly, $x$-year hedge ratio is the fraction of the $x$-year expected gold production hedged.

Hedging Dummy: Equals one if a firm is hedging (using derivatives) in a specific time period and is zero otherwise. Total hedging dummy equals one if a firm uses derivatives with 1-3 years to maturity and equals zero otherwise. $x$-year hedging dummy equals one if a firm uses derivatives with $x$-year maturity and equals zero otherwise. 
Speculation: Total speculation is the standard deviation of the quarterly total hedge ratios and $x$ year speculation is the standard deviation of the quarterly $x$-year hedge ratios.

Insider ownership: Calculated as the number of shares owned by directors and executives (obtained manually from proxy statements) multiplied by the end-of-year stock price.

Leverage: Calculated as the book value of long-term debt divided by the sum of book values of preferred stock, common equity, and long-term debt.

Market-to-book ratio of assets: Market value of assets divided by book value of assets. The market value of assets equals the book value of assets minus the book value of common stock plus market value of equity.

Quick Ratio: Measure of corporate liquidity defined by the ratio: $($ cash + cash equivalents + receivables) / current liabilities.

Altman's Z-score: Defined as: $Z=1.20 * X_{1}+1.40 * X_{2}+3.30 * X_{3}+0.60 * X_{4}+0.999 * X_{5}$ where $X_{1}=$ working capital (current assets - current liabilities)/total assets; $X_{2}=$ retained earnings/total assets; $X_{3}=$ earnings before interest and taxes/total assets; $X_{4}=$ market value of equity/ book value of total debt; and $X_{5}=$ sales/total assets. 


\section{References}

Adam, Tim R. and Chitru S. Fernando, 2006, Hedging, Speculation, and Shareholder Value, Journal of Financial Economics 81, 283-309.

Adam, Tim R., 2002, Do Firms Use Derivatives to Reduce Their Dependence on External Capital Markets? European Finance Review 6, 163-187.

Altman, Edward I., 1968, "Financial Ratios, Discriminant Analysis and the Prediction of Corporate Bankruptcy," Journal of Finance 23, 589-609.

Beber, Alessandro and Daniela Fabbri, 2006, Who Times the Foreign Exchange Market? Corporate Speculation and CEO Characteristics. University of Lausanne and FAME Working Paper.

Bodnar, Gordon M., Gregory S. Hayt and Richard C. Marston, 1998 Wharton Survey of Derivatives Usage by U.S. Non-Financial Firms, Financial Management 27(4), 70-91.

Brown, Gregory W., Peter R. Crabb, and David Haushalter, 2006, Are Firms Successful at Selective Hedging? Journal of Business 79, 2925-2949.

Burns, Natasha, and Simi Kedia, 2006, The Impact of Performance-Based Compensation on Misreporting, Journal of Financial Economics 79, 35-67.

Campbell, Tim S. and William A. Kracaw, 1999, Optimal Speculation in the Presence of Costly External Financing. In "Corporate Risk: Strategies and Management," Gregory Brown and Donald Chew, editors, Risk Publications, London.

Coles, Jeffrey L., Naveen D. Daniel, and Lalitha Naveen, 2006, Managerial Incentives and Risk Taking, Journal of Financial Economics 79, 431-468.

Core, John and Wayne Guay, 2002, Estimating the Value of Employee Stock Option Portfolios and Their Sensitivities to Price and Volatility, Journal of Accounting Research 40, 613630.

DeMarzo, Peter M. and Darrell Duffie, 1995, Corporate Incentives for Hedging and Hedge Accounting, Review of Financial Studies 8, 743-772.

Denis, David J., Paul Hanouna and Atulya Sarin, 2006, Is There a Dark side to Incentive Compensation? Journal of Corporate Finance 12, 467-488.

Dolde, Walter, 1993, The Trajectory of Corporate Financial Risk Management, Journal of Applied Corporate Finance 6, 33-41.

Faulkender, Michael W., 2005, Hedging or Market Timing? Selecting the Interest Rate Exposure of Corporate Debt, Journal of Finance 60, 931-962.

Faulkender, Michael W. and Sergey Chernenko, 2007, Interest Rate Swap Speculation and Managerial Compensation, Washington University in St. Louis Working Paper.

Froot, Kenneth A., David S. Scharfstein and Jeremy C. Stein, 1993, Risk Management: Coordinating Corporate Investment and Financing Policies, Journal of Finance 48, 16291658. 
Géczy, Christopher, Bernadette A. Minton, and Catherine M. Schrand, 2007, Taking a View: Corporate Speculation, Governance, and Compensation, Journal of Finance 62, 2405 2443.

Glaum, Martin, 2002, The Determinants of Selective Exchange Risk Management - Evidence from German Non-Financial Corporations, Journal of Applied Corporate Finance, 14, $108-121$.

Graham, John R. and Campbell R. Harvey, 2001, The Theory and Practice of Corporate Finance: Evidence from the Field, Journal of Financial Economics 60, 187-243.

Guay, Wayne R., 1999, The Sensitivity of CEO Wealth to Equity Risk: An Analysis of the Magnitude and Determinants, Journal of Financial Economics 53, 43-71.

Haushalter, David, 2000, Financing Policy, Basis Risk, and Corporate Hedging: Evidence from Oil and Gas Producers, Journal of Finance 55, 107-152.

Heckman, James J., 1979, Sample Selection as a Specification Error, Econometrica 47, 153-161.

Jensen, Michael C. and William H. Meckling, 1976, Theory of the Firm: Managerial Behavior, Agency Costs and Ownership Structure, Journal of Financial Economics 3, 305-360.

Jin, Yanbo and Philippe Jorion, 2006, Firm Value and Hedging: Evidence from U.S. Oil and Gas Producers, Journal of Finance 61: 893-919.

Mello, Antonio and John Parsons, 2000, Hedging and Liquidity, Review of Financial Studies 13, $127-153$.

Mian, Shehzad L., 1996, Evidence on Corporate Hedging Policy, Journal of Financial and Quantitative Analysis 31, 419-439.

Myers, Stewart C., 1977, Determinants of Corporate Borrowing, Journal of Financial Economics $5,147-175$.

Petersen, Mitchell A., 2008, Estimating Standard Errors in Finance Panel Data Sets: Comparing Approaches, Review of Financial Studies, forthcoming.

Smith, Clifford, and René M. Stulz, 1985, The Determinants of Firms' Hedging Policies, Journal of Financial and Quantitative Analysis 20, 391-405.

Stulz, René M., 1984, Optimal Hedging Policies, Journal of Financial and Quantitative Analysis $19,127-140$.

Stulz, René M., 1990, Managerial Discretion and Optimal Financing Policies, Journal of Financial Economics 26, 3-27.

Stulz, René M., 1996, Rethinking Risk Management, Journal of Applied Corporate Finance 9, 8-24.

Tufano, Peter, 1996, Who Manages Risk? An Empirical Examination of Risk Management Practices in the Gold Mining Industry, Journal of Finance 51, 1097-1137. 
Table 1

Firm Characteristics, Derivatives Usage, and CEO/CFO Compensation

This table presents summary statistics of firm characteristics, derivatives usage, and CEO/CFO compensation for 92 North American gold mining companies between 1989 and 1999. Firm size is the log of the market value of assets in millions of US\$. Market-to-book ratio is the market value of assets divided by the book value of assets. Dividend dummy is a dummy variable that equals one if a firm paid cash dividends in year $t$ and zero otherwise. Quick ratio equals [(cash + cash equivalents + receivables) / current liabilities]. Leverage is the ratio of the book value of debt to the book value of preferred stock, common stock and long-term debt. Altman's Z-score is calculated following Altman (1968). Total hedging dummy equals one if a firm uses derivatives with 1-3 years to maturity and is equal to zero otherwise. $x$-year hedging dummy equals one if a firm uses derivatives with $x$-year maturity and equals zero otherwise. Total hedge ratio is the fraction of the future 3-year expected gold production hedged each quarter, calculated by dividing the 3-year portfolio delta by the expected production over the next three years. $x$-year hedge ratio is the fraction of the $x$-year expected gold production hedged each quarter. Total speculation is the standard deviation of the quarterly total hedge ratios. $x$-year speculation is the standard deviation of the quarterly $x$-year hedge ratios. CEO and CFO compensation deltas and vegas are calculated as in Core and Guay (2002). Insider ownership is the dollar value of insider stock holdings, where insiders include all executives and board directors.

\begin{tabular}{|c|c|c|c|c|}
\hline & Mean & Median & Std. Dev & Obs. \\
\hline \multicolumn{5}{|l|}{ Panel A. Firm Characteristics } \\
\hline Firm size & 5.5867 & 5.458 & 1.7537 & 534 \\
\hline Market-to-book ratio of assets & 1.8586 & 1.564 & 1.1234 & 534 \\
\hline Dividend dummy & 0.4323 & 0 & 0.4959 & 539 \\
\hline Quick Ratio & 3.6598 & 1.618 & 8.5898 & 531 \\
\hline Leverage & 0.5172 & 0.190 & 1.2883 & 530 \\
\hline Altman's Z-score & 2.5486 & 2.471 & 1.8544 & 419 \\
\hline \multicolumn{5}{|c|}{ Panel B. Derivatives Usage Characteristics } \\
\hline Total hedging dummy & 0.7547 & 1 & 0.4307 & 534 \\
\hline 1- year hedging dummy & 0.7232 & 1 & 0.4479 & 495 \\
\hline 2-year hedging dummy & 0.5752 & 1 & 0.4948 & 499 \\
\hline 3-year hedging dummy & 0.4251 & 0 & 0.4949 & 501 \\
\hline Total hedge ratio & 0.2041 & 0.1155 & 0.252 & 1909 \\
\hline 1-year hedge ratio & 0.3474 & 0.2295 & 0.4406 & 2000 \\
\hline 2-year hedge ratio & 0.1875 & 0.03 & 0.2859 & 2002 \\
\hline 3-year hedge ratio & 0.0924 & 0 & 0.1901 & 2020 \\
\hline Total speculation & 0.0771 & 0.0543 & 0.0739 & 174 \\
\hline 1-year speculation & 0.2050 & 0.1590 & 0.2837 & 371 \\
\hline 2-year speculation & 0.1243 & 0.0882 & 0.1525 & 340 \\
\hline 3-year speculation & 0.0874 & 0.0545 & 0.1045 & 256 \\
\hline \multicolumn{5}{|c|}{ Panel C. CEO/CFO Compensation Characteristics } \\
\hline Log (delta of CEO compensation) & 10.2445 & 10.0302 & 1.9721 & 274 \\
\hline Log (delta of CFO compensation) & 9.1782 & 9.5058 & 3.0420 & 139 \\
\hline Log (vega of CEO compensation) & 8.4939 & 8.9066 & 2.9067 & 293 \\
\hline Log (vega of CFO compensation) & 7.2826 & 8.0123 & 2.8142 & 202 \\
\hline Log (insider ownership) & 15.7774 & 15.6146 & 2.0597 & 205 \\
\hline
\end{tabular}


Table 2

\section{Speculation and Firm Characteristics (OLS Regressions)}

This table presents the OLS regression results for speculation as a function of firm characteristics. For $x$-year speculation the sample is restricted to firms that hedge $x$ years ahead for $x=1,2$, and 3. For total speculation, the sample is restricted to firms that hedge 1, 2, or 3 years ahead. Firm size is the log of the market value of assets in millions of US\$. Altman's Z-score is calculated following Altman (1968). Total speculation is the standard deviation of the quarterly total hedge ratios and $x$-year speculation is the standard deviation of the quarterly $x$-year hedge ratios. Figures in parentheses denote $t$-statistics based on clustered (by firm) standard errors. * $* *$, and $* * *$ denote significance at the 10,5 , and $1 \%$ levels respectively.

\begin{tabular}{|c|c|c|c|c|c|c|c|c|c|c|c|c|}
\hline & \multicolumn{3}{|c|}{ Total Speculation } & \multicolumn{3}{|c|}{ 1-Year Speculation } & \multicolumn{3}{|c|}{ 2-Year Speculation } & \multicolumn{2}{|c|}{ 3-Year Speculation } & $\begin{array}{l}\text { XII } \\
\text { tion } \\
\end{array}$ \\
\hline Firm size & $\begin{array}{c}-0.012 * * * \\
(-2.77)\end{array}$ & & & $\begin{array}{c}-0.031 * * * \\
(-3.44)\end{array}$ & & & $\begin{array}{c}-0.026^{* * *} \\
(-3.09)\end{array}$ & & & $\begin{array}{l}-0.006 \\
(-0.70)\end{array}$ & & \\
\hline Z score & & $\begin{array}{c}-0.017 * * * \\
(-4.54)\end{array}$ & $\begin{array}{c}-0.050 * * * \\
(-3.26)\end{array}$ & & $\begin{array}{c}-0.028 * * \\
(-2.37)\end{array}$ & $\begin{array}{l}-0.066 \\
(-1.62)\end{array}$ & & $\begin{array}{c}-0.023^{* * *} \\
(-2.67)\end{array}$ & $\begin{array}{c}-0.062 * \\
(-1.83)\end{array}$ & & $\begin{array}{c}-0.012 * \\
(-1.72)\end{array}$ & $\begin{array}{c}-0.055^{* * *} \\
(-3.33)\end{array}$ \\
\hline$Z$ score $^{2}$ & & & $\begin{array}{c}0.006^{* *} \\
(2.65)\end{array}$ & & & $\begin{array}{l}0.007 \\
(1.20)\end{array}$ & & & $\begin{array}{l}0.008 \\
(1.42)\end{array}$ & & & $\begin{array}{c}0.008^{* *} \\
(2.48)\end{array}$ \\
\hline Intercept & $\begin{array}{c}0.153 * * * \\
(4.98)\end{array}$ & $\begin{array}{c}0.117 * * * \\
(9.25)\end{array}$ & $\begin{array}{c}0.141^{* * *} \\
(6.85) \\
\end{array}$ & $\begin{array}{c}0.388 * * * \\
(5.96)\end{array}$ & $\begin{array}{c}0.273 * * * \\
(5.96) \\
\end{array}$ & $\begin{array}{c}0.299 * * * \\
(4.74)\end{array}$ & $\begin{array}{c}0.290 * * * \\
(4.94) \\
\end{array}$ & $\begin{array}{c}0.193 * * * \\
(5.85) \\
\end{array}$ & $\begin{array}{c}0.221^{* * *} \\
(4.62) \\
\end{array}$ & $\begin{array}{c}0.128^{* *} \\
(2.56) \\
\end{array}$ & $\begin{array}{c}0.121 * * * \\
(7.52)\end{array}$ & $\begin{array}{c}0.152 * * * \\
(7.81) \\
\end{array}$ \\
\hline Observations & 174 & 155 & 155 & 335 & 284 & 284 & 267 & 231 & 231 & 206 & 183 & 183 \\
\hline R-squared & 0.05 & 0.14 & 0.19 & 0.03 & 0.03 & 0.03 & 0.07 & 0.05 & 0.07 & 0.01 & 0.03 & 0.07 \\
\hline
\end{tabular}


Table 3

\section{Speculation and Firm Characteristics (Heckman Two-step Regressions)}

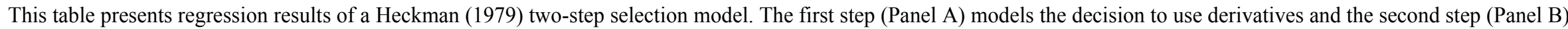

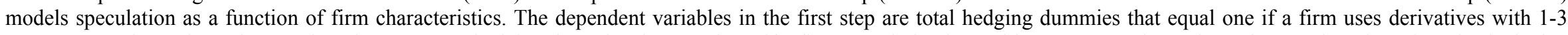

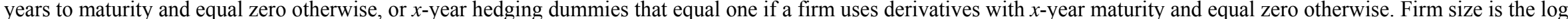

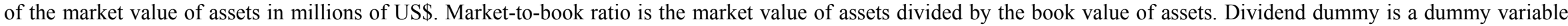

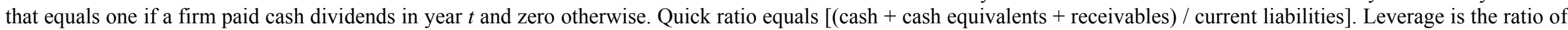

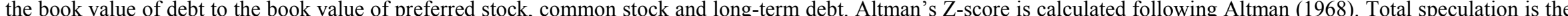

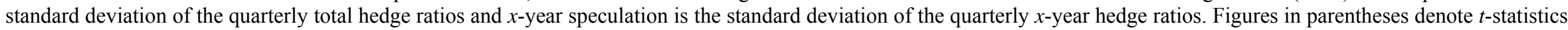
with robust standard errors. $* * *$, and $* * *$ denote significance at the 10,5 , and $1 \%$ levels respectively.

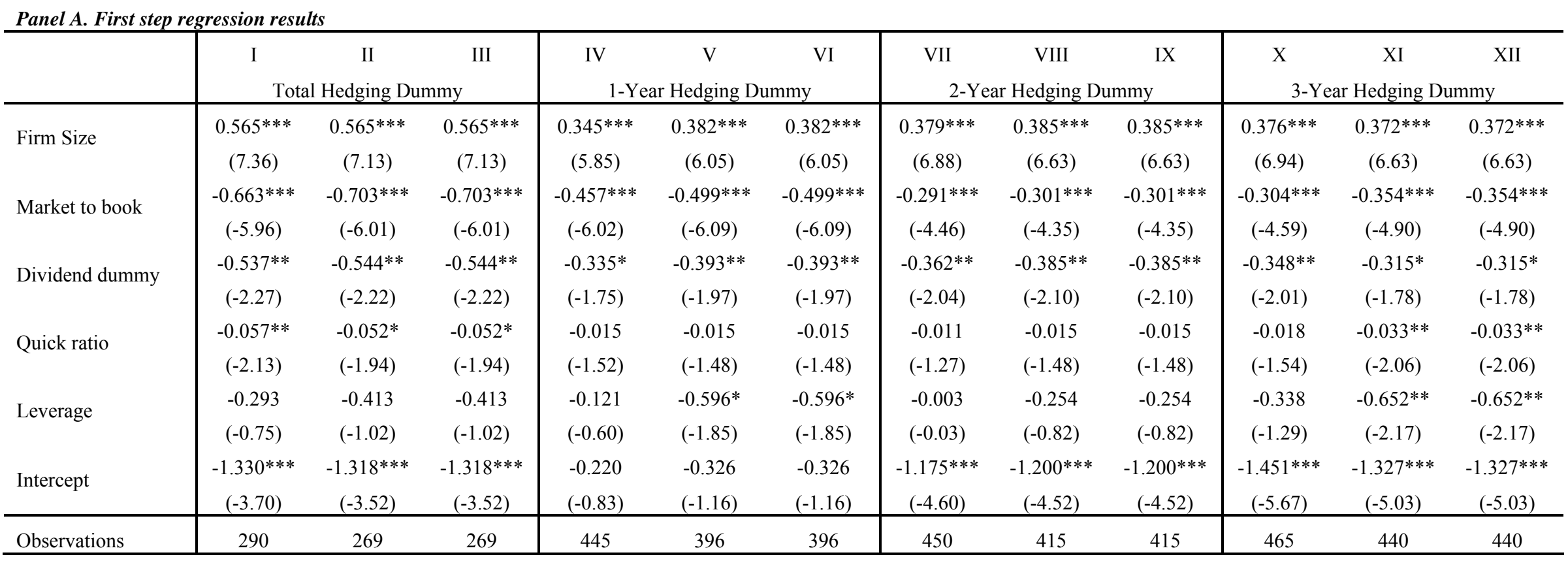


Table 3 (contd.)

\begin{tabular}{|c|c|c|c|c|c|c|c|c|c|c|c|c|}
\hline \multirow[b]{2}{*}{ Firm size } & \multicolumn{3}{|c|}{ Total Speculation } & \multicolumn{3}{|c|}{ 1-Year Speculation } & \multicolumn{3}{|c|}{ 2-Year Speculation } & \multicolumn{3}{|c|}{ 3-Year Speculation } \\
\hline & $\begin{array}{c}-0.021 * * * \\
(-4.40)\end{array}$ & $\begin{array}{c}-0.016 * * * \\
(-2.73)\end{array}$ & $\begin{array}{c}-0.016 * * * \\
(-2.67)\end{array}$ & $\begin{array}{c}-0.039 * * * \\
(-3.57)\end{array}$ & $\begin{array}{c}-0.032 * * \\
(-2.35)\end{array}$ & $\begin{array}{c}-0.031^{* *} \\
(-2.25)\end{array}$ & $\begin{array}{c}-0.038 * * * \\
(-4.22)\end{array}$ & $\begin{array}{c}-0.030 * * * \\
(-2.68)\end{array}$ & $\begin{array}{c}-0.029 * * * \\
(-2.59)\end{array}$ & $\begin{array}{c}-0.018 * * * \\
(-2.62)\end{array}$ & $\begin{array}{c}-0.014^{*} \\
(-1.77)\end{array}$ & $\begin{array}{l}-0.012 \\
(-1.54)\end{array}$ \\
\hline$Z$ score & & $\begin{array}{c}-0.010 * * \\
(-2.29)\end{array}$ & $\begin{array}{c}-0.039 * * * \\
(-3.29)\end{array}$ & & $\begin{array}{c}-0.022 * * \\
(-1.99)\end{array}$ & $\begin{array}{l}-0.036 \\
(-0.92)\end{array}$ & & $\begin{array}{c}-0.014 * \\
(-1.89)\end{array}$ & $\begin{array}{l}-0.039 \\
(-1.60)\end{array}$ & & $\begin{array}{l}-0.006 \\
(-1.21)\end{array}$ & $\begin{array}{c}-0.050 * * * \\
(-2.92)\end{array}$ \\
\hline$Z$ score $^{2}$ & & & $\begin{array}{c}0.006 * * * \\
(2.63)\end{array}$ & & & $\begin{array}{l}0.003 \\
(0.37)\end{array}$ & & & $\begin{array}{l}0.005 \\
(1.08)\end{array}$ & & & $\begin{array}{c}0.008 * * * \\
(2.66)\end{array}$ \\
\hline Inverse Mills Ratio & $\begin{array}{c}-0.071 * * * \\
(-3.27)\end{array}$ & $\begin{array}{c}-0.045^{*} \\
(-1.86)\end{array}$ & $\begin{array}{c}-0.056^{* *} \\
(-2.31)\end{array}$ & $\begin{array}{l}-0.112 \\
(-1.48)\end{array}$ & $\begin{array}{l}-0.003 \\
(-0.03)\end{array}$ & $\begin{array}{l}-0.008 \\
(-0.10)\end{array}$ & $\begin{array}{l}-0.092 * \\
(-1.76)\end{array}$ & $\begin{array}{l}-0.048 \\
(-0.82)\end{array}$ & $\begin{array}{l}-0.058 \\
(-0.97)\end{array}$ & $\begin{array}{c}-0.089 * * * \\
(-2.61)\end{array}$ & $\begin{array}{c}-0.071^{* *} \\
(-2.00)\end{array}$ & $\begin{array}{c}-0.083 * * \\
(-2.33)\end{array}$ \\
\hline Intercept & $\begin{array}{c}0.246^{* * *} \\
(6.39) \\
\end{array}$ & $\begin{array}{c}0.226^{* * *} \\
(5.35) \\
\end{array}$ & $\begin{array}{c}0.249 * * * \\
(5.78) \\
\end{array}$ & $\begin{array}{c}0.477 * * * \\
(5.60) \\
\end{array}$ & $\begin{array}{c}0.447 * * * \\
(4.64) \\
\end{array}$ & $\begin{array}{c}0.454 * * * \\
(4.63) \\
\end{array}$ & $\begin{array}{c}0.421 * * * \\
(5.20) \\
\end{array}$ & $\begin{array}{c}0.385 * * * \\
(4.18) \\
\end{array}$ & $\begin{array}{c}0.404 * * * \\
(4.30) \\
\end{array}$ & $\begin{array}{c}0.273 * * * \\
(4.22) \\
\end{array}$ & $\begin{array}{c}0.254 * * * \\
(3.75) \\
\end{array}$ & $\begin{array}{c}0.284 * * * \\
(4.13) \\
\end{array}$ \\
\hline Observations & 171 & 150 & 150 & 321 & 272 & 272 & 258 & 223 & 223 & 202 & 177 & 177 \\
\hline$\chi^{2}$ & 73.51 & 80.73 & 87.75 & 47.04 & 52.25 & 52.40 & 65.16 & 65.52 & 66.63 & 55.09 & 52.37 & 59.60 \\
\hline $\operatorname{Pr}>\chi^{2}$ & 0.0000 & 0.0000 & 0.0000 & 0.0000 & 0.0000 & 0.0000 & 0.0000 & 0.0000 & 0.0000 & 0.0000 & 0.0000 & 0.0000 \\
\hline
\end{tabular}


Table 4

Speculation and CEO/CFO Compensation Characteristics (OLS Regressions)

This table presents the OLS regression results for speculation as a function of CEO/CFO compensation characteristics. For $x$-year speculation the sample is restricted to firms that hedge $x$ years ahead for $x=1,2$, and 3. For total speculation, the sample is restricted to firms that hedge 1,2, or 3 years ahead. Total speculation is the standard deviation of the quarterly total hedge ratios and $x$-year speculation is the standard deviation of the quarterly $x$-year hedge ratios. Firm size is the log of the market value of assets in millions of US\$. CEO and CFO compensation deltas and vegas are calculated as in Core and Guay (2002). Figures in parentheses denote $t$-statistics based on clustered (by firm) standard errors. ${ }^{*}, * *$, and $* * *$ denote significance at the 10,5 , and $1 \%$ levels respectively.

Panel A. Speculation and CEO compensation

\begin{tabular}{|c|c|c|c|c|c|c|c|c|}
\hline & $\begin{array}{c}\mathrm{I} \\
\text { Total S } \\
\end{array}$ & $\begin{array}{c}\text { II } \\
\text { culation } \\
\end{array}$ & $\begin{array}{c}\text { III } \\
\text { 1-Year S } \\
\end{array}$ & $\begin{array}{c}\text { IV } \\
\text { eculation } \\
\end{array}$ & $\begin{array}{c}\mathrm{V} \\
\text { 2-Year S } \\
\end{array}$ & $\begin{array}{c}\text { VI } \\
\text { eculation } \\
\end{array}$ & $\begin{array}{c}\text { VII } \\
3 \text {-Year }\end{array}$ & $\begin{array}{r}\text { VIII } \\
\text { culation } \\
\end{array}$ \\
\hline $\begin{array}{l}\text { Log (delta of CEO } \\
\text { compensation) }\end{array}$ & $\begin{array}{l}-0.007 \\
(-1.57)\end{array}$ & & $\begin{array}{c}-0.014 * * \\
(-2.19)\end{array}$ & & $\begin{array}{l}-0.018^{*} \\
(-1.91)\end{array}$ & & $\begin{array}{l}0.001 \\
(0.23)\end{array}$ & \\
\hline $\begin{array}{l}\text { Log (vega of CEO } \\
\text { compensation) }\end{array}$ & & $\begin{array}{c}-0.010 * * \\
(-2.23)\end{array}$ & & $\begin{array}{l}-0.008^{*} \\
(-1.70)\end{array}$ & & $\begin{array}{l}-0.009 \\
(-1.62)\end{array}$ & & $\begin{array}{l}-0.001 \\
(-0.16)\end{array}$ \\
\hline Constant & $\begin{array}{c}0.148 * * * \\
(3.00) \\
\end{array}$ & $\begin{array}{c}0.166^{* * *} \\
(3.85) \\
\end{array}$ & $\begin{array}{c}0.313 * * * \\
(4.60) \\
\end{array}$ & $\begin{array}{c}0.239 * * * \\
(5.75) \\
\end{array}$ & $\begin{array}{c}0.302 * * * \\
(2.81) \\
\end{array}$ & $\begin{array}{c}0.195 * * * \\
(3.25) \\
\end{array}$ & $\begin{array}{l}0.073 \\
(1.44) \\
\end{array}$ & $\begin{array}{c}0.091^{* *} \\
(2.28) \\
\end{array}$ \\
\hline Observations & 116 & 120 & 222 & 236 & 204 & 217 & 127 & 133 \\
\hline R-squared & 0.05 & 0.09 & 0.03 & 0.02 & 0.05 & 0.02 & 0.00 & 0.00 \\
\hline
\end{tabular}

Panel B. Speculation and CFO compensation

\begin{tabular}{|c|c|c|c|c|c|c|c|c|}
\hline & \multicolumn{2}{|c|}{ Total Speculation } & \multicolumn{2}{|c|}{ 1-Year Speculation } & \multicolumn{2}{|c|}{ 2-Year Speculation } & \multicolumn{2}{|c|}{ 3-Year Speculation } \\
\hline $\begin{array}{l}\text { Log (delta of CFO } \\
\text { compensation) }\end{array}$ & $\begin{array}{c}-0.007 * * \\
(-2.13)\end{array}$ & & $\begin{array}{c}-0.023 * * * \\
(-4.26)\end{array}$ & & $\begin{array}{c}-0.010 * * * \\
(-3.01)\end{array}$ & & $\begin{array}{l}0.002 \\
(0.31)\end{array}$ & \\
\hline $\begin{array}{l}\text { Log (vega of CFO } \\
\text { compensation) }\end{array}$ & & $\begin{array}{c}-0.011^{* *} \\
(-2.09)\end{array}$ & & $\begin{array}{c}-0.018^{* * *} \\
(-3.40)\end{array}$ & & $\begin{array}{l}-0.012 \\
(-1.62)\end{array}$ & & $\begin{array}{l}-0.007 \\
(-1.36)\end{array}$ \\
\hline Constant & $\begin{array}{c}0.136^{* * *} \\
(3.59) \\
\end{array}$ & $\begin{array}{c}0.166^{* * *} \\
(3.57) \\
\end{array}$ & $\begin{array}{c}0.392 * * * \\
(6.80) \\
\end{array}$ & $\begin{array}{c}0.320^{* * *} \\
(6.73) \\
\end{array}$ & $\begin{array}{c}0.184^{* * *} \\
(4.99) \\
\end{array}$ & $\begin{array}{c}0.217 * * * \\
(2.97) \\
\end{array}$ & $\begin{array}{l}0.060 \\
(0.92) \\
\end{array}$ & $\begin{array}{c}0.138 * * * \\
(3.14) \\
\end{array}$ \\
\hline Observations & 60 & 87 & 110 & 161 & 103 & 150 & 68 & 96 \\
\hline R-squared & 0.10 & 0.10 & 0.11 & 0.08 & 0.10 & 0.03 & 0.00 & 0.02 \\
\hline
\end{tabular}


Table 5

Speculation and CEO Compensation Characteristics (Heckman Two-step Regressions)

This table presents the regression results of the second step of a Heckman (1979) two-step selection model, which models speculation as a function of CEO compensation characteristics. For $x$-year speculation the sample is restricted to firms that hedge $x$ years ahead for $x=1,2$, and 3. For total speculation, the sample is restricted to firms that hedge 1, 2, or 3 years ahead. Total speculation is the standard deviation of the quarterly total hedge ratios and $x$-year speculation is the standard deviation of the quarterly $x$-year hedge ratios. Firm size is the log of the market value of assets in millions of US\$. CEO compensation deltas and vegas are calculated as in Core and Guay (2002). Figures in parentheses denote $t$-statistics with robust standard errors. *, $* *$, and $* * *$ denote significance at the 10,5 , and $1 \%$ levels respectively.

\begin{tabular}{|c|c|c|c|c|c|c|c|c|}
\hline & $\begin{array}{l}\text { I } \\
\text { Total } \mathrm{S}_{1}\end{array}$ & $\begin{array}{c}\text { II } \\
\text { culation }\end{array}$ & $\begin{array}{l}\text { III } \\
1-\text { Year S }\end{array}$ & $\begin{array}{c}\text { IV } \\
\text { peculation }\end{array}$ & $\begin{array}{c}\text { V } \\
\text { 2-Year S }\end{array}$ & VI & $\begin{array}{l}\text { VII } \\
\text { 3-Year } s\end{array}$ & $\begin{array}{r}\text { VIII } \\
\text { eculation }\end{array}$ \\
\hline Firm size & & $\begin{array}{c}-0.018^{* * *} \\
(-3.49)\end{array}$ & & $\begin{array}{c}-0.030 * * * \\
(-4.37)\end{array}$ & & $\begin{array}{c}-0.041 * * * \\
(-2.73)\end{array}$ & & $\begin{array}{l}-0.014^{*} \\
(-1.70)\end{array}$ \\
\hline $\begin{array}{l}\text { Log (delta of CEO } \\
\text { compensation) }\end{array}$ & $\begin{array}{c}-0.007 * * \\
(-2.32)\end{array}$ & $\begin{array}{l}-0.003 \\
(-1.02)\end{array}$ & $\begin{array}{c}-0.009 * * \\
(-1.99)\end{array}$ & $\begin{array}{l}-0.000 \\
(-0.04)\end{array}$ & $\begin{array}{c}-0.022^{* * *} \\
(-2.74)\end{array}$ & $\begin{array}{c}-0.016^{* *} \\
(-2.02)\end{array}$ & $\begin{array}{l}-0.002 \\
(-0.42)\end{array}$ & $\begin{array}{l}0.000 \\
(0.10)\end{array}$ \\
\hline Inverse Mills Ratio & $\begin{array}{l}-0.014 \\
(-0.87)\end{array}$ & $\begin{array}{c}-0.046^{* *} \\
(-2.50)\end{array}$ & $\begin{array}{l}0.014 \\
(0.50)\end{array}$ & $\begin{array}{l}-0.050 \\
(-1.57)\end{array}$ & $\begin{array}{l}-0.008 \\
(-0.17)\end{array}$ & $\begin{array}{c}-0.124 * * \\
(-2.02)\end{array}$ & $\begin{array}{c}-0.054 * * \\
(-2.32)\end{array}$ & $\begin{array}{c}-0.084 * * * \\
(-2.79)\end{array}$ \\
\hline Intercept & $\begin{array}{c}0.152 * * * \\
(4.38) \\
\end{array}$ & $\begin{array}{c}0.248^{* * *} \\
(5.66) \\
\end{array}$ & $\begin{array}{c}0.250 * * * \\
(4.80) \\
\end{array}$ & $\begin{array}{c}0.376^{* * *} \\
(6.49) \\
\end{array}$ & $\begin{array}{c}0.356^{* * *} \\
(3.59) \\
\end{array}$ & $\begin{array}{c}0.644 * * * \\
(4.42) \\
\end{array}$ & $\begin{array}{c}0.150^{* * *} \\
(2.66) \\
\end{array}$ & $\begin{array}{c}0.242 * * * \\
(3.02) \\
\end{array}$ \\
\hline $\begin{array}{l}\text { Observations } \\
\chi^{2}\end{array}$ & $\begin{array}{c}114 \\
5.402\end{array}$ & $\begin{array}{c}114 \\
69.76\end{array}$ & $\begin{array}{c}196 \\
3.946\end{array}$ & $\begin{array}{c}196 \\
68.53\end{array}$ & $\begin{array}{c}155 \\
7.508\end{array}$ & $\begin{array}{c}155 \\
70.38\end{array}$ & $\begin{array}{c}124 \\
0.173\end{array}$ & $\begin{array}{c}124 \\
59.46\end{array}$ \\
\hline $\operatorname{Pr}>\chi^{2}$ & 0.0201 & 0.0000 & 0.0470 & 0.0000 & 0.00614 & 0.0000 & 0.678 & 0.0000 \\
\hline
\end{tabular}

Panel B. Speculation and vega of CEO compensation

\begin{tabular}{|c|c|c|c|c|c|c|c|c|}
\hline & $\begin{array}{l}\text { IX } \\
\text { Total S }\end{array}$ & $\begin{array}{r}\mathrm{X} \\
\text { culation } \\
\end{array}$ & $\begin{array}{c}\text { XI } \\
1-Y \text { ear } \mathrm{S}\end{array}$ & $\begin{array}{c}\text { XII } \\
\text { peculation } \\
\end{array}$ & $\begin{array}{l}\text { XIII } \\
\text { 2-Year S }\end{array}$ & $\begin{array}{r}\text { XIV } \\
\text { eculation } \\
\end{array}$ & $\begin{array}{l}\text { XV } \\
\text { 3-Year }\end{array}$ & $\begin{array}{r}\text { XVI } \\
\text { eculation } \\
\end{array}$ \\
\hline Firm size & & $\begin{array}{c}-0.015^{* * *} \\
(-2.99)\end{array}$ & & $\begin{array}{c}-0.026 * * * \\
(-3.94)\end{array}$ & & $\begin{array}{c}-0.042 * * * \\
(-2.89)\end{array}$ & & $\begin{array}{l}-0.011 \\
(-1.41)\end{array}$ \\
\hline $\begin{array}{l}\text { Log (vega of CEO } \\
\text { compensation) }\end{array}$ & $\begin{array}{c}-0.010 * * * \\
(-3.37)\end{array}$ & $\begin{array}{c}-0.006^{* *} \\
(-2.15)\end{array}$ & $\begin{array}{c}-0.009 * * \\
(-2.38)\end{array}$ & $\begin{array}{l}-0.004 \\
(-0.91)\end{array}$ & $\begin{array}{c}-0.019 * * * \\
(-2.82)\end{array}$ & $\begin{array}{c}-0.015^{* *} \\
(-2.19)\end{array}$ & $\begin{array}{l}-0.005 \\
(-1.33)\end{array}$ & $\begin{array}{l}-0.004 \\
(-0.81)\end{array}$ \\
\hline Inverse Mills Ratio & $\begin{array}{l}-0.025 \\
(-1.53)\end{array}$ & $\begin{array}{c}-0.051 * * * \\
(-2.80)\end{array}$ & $\begin{array}{l}0.002 \\
(0.06)\end{array}$ & $\begin{array}{l}-0.057^{*} \\
(-1.77)\end{array}$ & $\begin{array}{l}-0.008 \\
(-0.18)\end{array}$ & $\begin{array}{c}-0.130 * * \\
(-2.15)\end{array}$ & $\begin{array}{c}-0.063 * * * \\
(-2.80)\end{array}$ & $\begin{array}{c}-0.088 * * * \\
(-2.99)\end{array}$ \\
\hline Intercept & $\begin{array}{c}0.176^{* * *} \\
(5.70)\end{array}$ & $\begin{array}{c}0.261 * * * \\
(6.21) \\
\end{array}$ & $\begin{array}{c}0.247 * * * \\
(6.07) \\
\end{array}$ & $\begin{array}{c}0.389 * * * \\
(7.24) \\
\end{array}$ & $\begin{array}{c}0.304 * * * \\
(3.89) \\
\end{array}$ & $\begin{array}{c}0.621 * * * \\
(4.59) \\
\end{array}$ & $\begin{array}{c}0.190 * * * \\
(3.79) \\
\end{array}$ & $\begin{array}{c}0.265^{* * *} \\
(3.52) \\
\end{array}$ \\
\hline $\begin{array}{l}\text { Observations } \\
\chi^{2} \\
\operatorname{Pr}>\chi^{2}\end{array}$ & $\begin{array}{c}118 \\
11.38 \\
0.000743\end{array}$ & 73.93 & $\begin{array}{c}202 \\
5.659\end{array}$ & 68.16 & 0.00485 & 73.60 & 1.763 & $\begin{array}{c}128 \\
62.17\end{array}$ \\
\hline
\end{tabular}


Table 6

Speculation and CFO Compensation Characteristics (Heckman Two-step Regressions)

This table presents the regression results of the second step of a Heckman (1979) two-step selection model, which models speculation as a function of CFO compensation characteristics. For $x$-year speculation the sample is restricted to firms that hedge $x$ years ahead for $x=1,2$, and 3. For total speculation, the sample is restricted to firms that hedge 1,2, or 3 years ahead. Total speculation is the standard deviation of the quarterly total hedge ratios and $x$-year speculation is the standard deviation of the quarterly $x$-year hedge ratios. Firm size is the log of the market value of assets in millions of US\$. CFO compensation deltas and vegas are calculated as in Core and Guay (2002). Figures in parentheses denote $t$-statistics with robust standard errors. ${ }^{*}, *$, and $* *$ denote significance at the 10,5 , and $1 \%$ levels respectively.

Panel A. Speculation and delta of CFO compensation

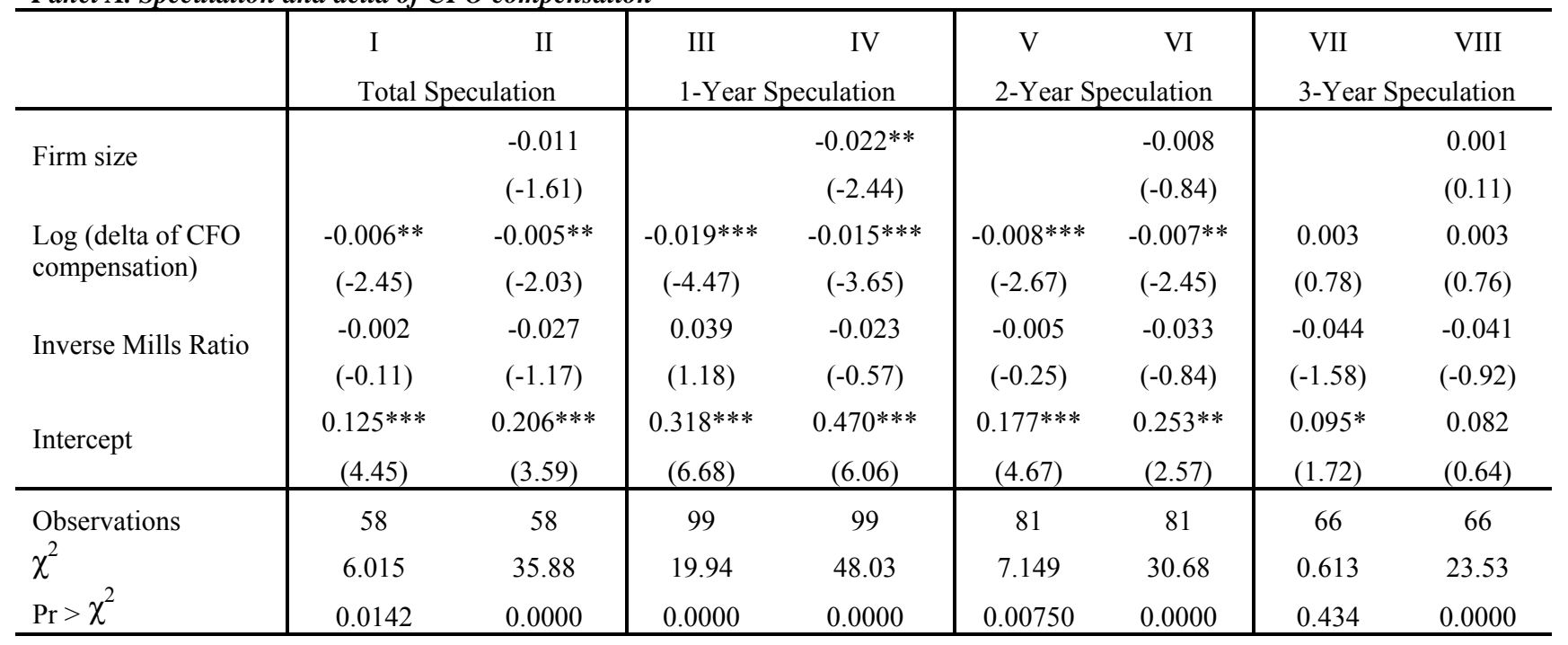

Panel B. Speculation and vega of CFO compensation

\begin{tabular}{|c|c|c|c|c|c|c|c|c|}
\hline & \multicolumn{2}{|c|}{ Total Speculation } & \multicolumn{2}{|c|}{ 1-Year Speculation } & \multicolumn{2}{|c|}{ 2-Year Speculation } & \multicolumn{2}{|c|}{ 3-Year Speculation } \\
\hline Firm size & & $\begin{array}{l}-0.006^{*} \\
(-1.88)\end{array}$ & & $\begin{array}{c}-0.020 * * * \\
(-2.65)\end{array}$ & & $\begin{array}{c}-0.061 * * * \\
(-3.07)\end{array}$ & & $\begin{array}{c}-0.025 * * * \\
(-2.93)\end{array}$ \\
\hline $\begin{array}{l}\text { Log (vega of CFO } \\
\text { compensation) }\end{array}$ & $\begin{array}{c}-0.009 * * * \\
(-2.73)\end{array}$ & $\begin{array}{c}-0.020 * * * \\
(-3.53)\end{array}$ & $\begin{array}{c}-0.017 * * * \\
(-4.13)\end{array}$ & $\begin{array}{c}-0.013 * * * \\
(-3.08)\end{array}$ & $\begin{array}{l}-0.014^{*} \\
(-1.68)\end{array}$ & $\begin{array}{l}-0.009 \\
(-1.08)\end{array}$ & $\begin{array}{l}-0.005 \\
(-1.19)\end{array}$ & $\begin{array}{l}-0.002 \\
(-0.55)\end{array}$ \\
\hline Inverse Mills Ratio & $\begin{array}{l}-0.017 \\
(-0.94)\end{array}$ & $\begin{array}{c}-0.051^{* * *} \\
(-2.61)\end{array}$ & $\begin{array}{l}-0.015 \\
(-0.50)\end{array}$ & $\begin{array}{l}-0.054 \\
(-1.63)\end{array}$ & $\begin{array}{l}0.002 \\
(0.03)\end{array}$ & $\begin{array}{c}-0.172 * * \\
(-2.15)\end{array}$ & $\begin{array}{l}-0.026 \\
(-1.12)\end{array}$ & $\begin{array}{c}-0.085 * * * \\
(-2.67)\end{array}$ \\
\hline Intercept & $\begin{array}{c}0.163 * * * \\
(5.13) \\
\end{array}$ & $\begin{array}{c}0.292 * * * \\
(6.08) \\
\end{array}$ & $\begin{array}{c}0.309 * * * \\
(8.03)\end{array}$ & $\begin{array}{c}0.426^{* * *} \\
(7.30) \\
\end{array}$ & $\begin{array}{c}0.242 * * * \\
(2.69) \\
\end{array}$ & $\begin{array}{c}0.729 * * * \\
(3.96)\end{array}$ & $\begin{array}{c}0.148 * * * \\
(3.17) \\
\end{array}$ & $\begin{array}{c}0.345^{* * * *} \\
(4.15) \\
\end{array}$ \\
\hline $\begin{array}{l}\text { Observations } \\
\chi^{2} \\
\operatorname{Pr}>\chi^{2}\end{array}$ & $\begin{array}{c}85 \\
7.477\end{array}$ & $\begin{array}{c}85 \\
59.65\end{array}$ & $\begin{array}{c}142 \\
17.09\end{array}$ & $\begin{array}{c}142 \\
60.21\end{array}$ & $\begin{array}{c}114 \\
2.825\end{array}$ & $\begin{array}{c}114 \\
50.75\end{array}$ & $\begin{array}{c}94 \\
1.428\end{array}$ & $\begin{array}{c}94 \\
48.60\end{array}$ \\
\hline
\end{tabular}


Table 7

\section{Additional Robustness Checks of Speculation and Firm/Compensation Characteristics (OLS Regressions)}

This table presents OLS regression results for speculation as a function of firm characteristics and CEO/CFO compensation characteristics, using two alternate measures of total speculation. The first alternate measure of total speculation ("Total speculation R1") is the standard deviation of the quarterly total hedge ratio defined as equal to [- Portfolio delta (1-3 year contracts)] / firm's gold reserves. The second alternate measure of total speculation ("Total speculation R2") is the standard deviation of the quarterly total hedge ratio defined as equal to [- Portfolio delta (1-5 year contracts)]/firm's gold reserves. For regressions using Total speculation R1, the sample is restricted to firms that hedge 1, 2, or 3 years ahead and for regressions using Total speculation R2, the sample is restricted to firms that hedge 1, 2, 3, 4 or 5 years ahead. Firm size is the log of the market value of assets in millions of US\$. Altman's Z-score is calculated following Altman (1968). CEO and CFO compensation deltas and vegas are calculated as in Core and Guay (2002). Figures in parentheses denote $t$-statistics based on clustered (by firm) standard errors. ${ }^{*}, *$, and $* * *$ denote significance at the 10,5 , and $1 \%$ levels respectively.

Panel A. Total speculation R1 [based on (1-3) year portfolio delta]

\begin{tabular}{|c|c|c|c|c|c|c|c|}
\hline & I & II & III & IV & V & VI & VII \\
\hline Firm size & $\begin{array}{c}-0.006 * * * \\
(-3.67)\end{array}$ & & & & & & \\
\hline Z score & & $\begin{array}{c}-0.004 * * \\
(-2.58)\end{array}$ & $\begin{array}{c}-0.015 * * \\
(-2.55)\end{array}$ & & & & \\
\hline$Z$ score $^{2}$ & & & $\begin{array}{c}0.002 * * \\
(2.16)\end{array}$ & & & & \\
\hline $\begin{array}{l}\text { Log (delta of CEO } \\
\text { compensation) }\end{array}$ & & & & $\begin{array}{c}-0.002 * * \\
(-2.31)\end{array}$ & & & \\
\hline $\begin{array}{l}\text { Log (vega of CEO } \\
\text { compensation) }\end{array}$ & & & & & $\begin{array}{l}-0.002 * \\
(-1.78)\end{array}$ & & \\
\hline $\begin{array}{l}\text { Log (delta of CFO } \\
\text { compensation) }\end{array}$ & & & & & & $\begin{array}{l}-0.002 * \\
(-1.98)\end{array}$ & \\
\hline $\begin{array}{l}\text { Log (vega of CFO } \\
\text { compensation) }\end{array}$ & & & & & & & $\begin{array}{c}-0.002 * * \\
(-2.23)\end{array}$ \\
\hline Intercept & $\begin{array}{c}0.061 * * * \\
(5.48) \\
\end{array}$ & $\begin{array}{c}0.035 * * * \\
(6.26) \\
\end{array}$ & $\begin{array}{c}0.042 * * * \\
(5.60) \\
\end{array}$ & $\begin{array}{c}0.040 * * * \\
(4.25)\end{array}$ & $\begin{array}{c}0.036^{* * *} \\
(3.58)\end{array}$ & $\begin{array}{c}0.037 * * * \\
(3.61)\end{array}$ & $\begin{array}{c}0.033 * * * \\
(4.69)\end{array}$ \\
\hline Observations & 290 & 244 & 244 & 186 & 195 & 93 & 133 \\
\hline R-squared & 0.09 & 0.04 & 0.06 & 0.02 & 0.03 & 0.04 & 0.04 \\
\hline
\end{tabular}


Table 7 (contd.)

\begin{tabular}{|c|c|c|c|c|c|c|c|}
\hline & I & II & III & IV & $\mathrm{V}$ & VI & VII \\
\hline Firm size & $\begin{array}{c}-0.006^{* * *} \\
(-3.51)\end{array}$ & & & & & & \\
\hline Z score & & $\begin{array}{c}-0.007 * * * \\
(-3.29)\end{array}$ & $\begin{array}{c}-0.028 * * * \\
(-3.14)\end{array}$ & & & & \\
\hline$Z$ score $^{2}$ & & & $\begin{array}{c}0.004 * * * \\
(2.84)\end{array}$ & & & & \\
\hline $\begin{array}{l}\text { Log (delta of CEO } \\
\text { compensation) }\end{array}$ & & & & $\begin{array}{c}-0.003 * * \\
(-2.25)\end{array}$ & & & \\
\hline $\begin{array}{l}\text { Log (vega of CEO } \\
\text { compensation) }\end{array}$ & & & & & $\begin{array}{l}-0.002 * \\
(-1.88)\end{array}$ & & \\
\hline $\begin{array}{l}\text { Log (delta of CFO } \\
\text { compensation) }\end{array}$ & & & & & & $\begin{array}{c}-0.002 * * \\
(-2.55)\end{array}$ & \\
\hline $\begin{array}{l}\text { Log (vega of CFO } \\
\text { compensation) }\end{array}$ & & & & & & & $\begin{array}{c}-0.002 * * \\
(-2.08)\end{array}$ \\
\hline Intercept & $\begin{array}{c}0.067 * * * \\
(5.38) \\
\end{array}$ & $\begin{array}{c}0.049 * * * \\
(5.86)\end{array}$ & $\begin{array}{c}0.063 * * * \\
(5.14)\end{array}$ & $\begin{array}{c}0.062 * * * \\
(3.45)\end{array}$ & $\begin{array}{c}0.046 * * * \\
(3.62)\end{array}$ & $\begin{array}{c}0.043 * * * \\
(3.94)\end{array}$ & $\begin{array}{c}0.043 * * * \\
(4.19) \\
\end{array}$ \\
\hline Observations & 310 & 261 & 261 & 198 & 208 & 102 & 146 \\
\hline R-squared & 0.05 & 0.07 & 0.11 & 0.02 & 0.02 & 0.02 & 0.02 \\
\hline
\end{tabular}


Table 8

Additional Robustness Checks of Speculation and Firm/Compensation Characteristics (Heckman Two-step Regressions)

This table presents the regression results of the second step of a Heckman (1979) two-step selection model, which models speculation as a function of firm characteristics and CEO/CFO compensation characteristics, using two alternate measures of total speculation. The first alternate measure of total speculation ("Total speculation R1") is the standard deviation of the quarterly total hedge ratio defined as equal to [- Portfolio delta (1-3 year contracts)] / firm's gold reserves. The second alternate measure of total speculation ("Total speculation R2") is the standard deviation of the quarterly total hedge ratio defined as equal to [- Portfolio delta (1-5 year contracts)] / firm's gold reserves. For regressions using Total speculation R1, the sample is restricted to firms that hedge 1, 2, or 3 years ahead and for regressions using Total speculation $\mathrm{R} 2$, the sample is restricted to firms that hedge 1,2,3,4 or 5 years ahead. Firm size is the log of the market value of assets in millions of US\$. Altman's Z-score is calculated following Altman (1968). CEO and CFO compensation deltas and vegas are calculated as in Core and Guay (2002). Figures in parentheses denote $t$-statistics with robust standard errors. *,**, and *** denote significance at the 10,5 , and $1 \%$ levels respectively.

Panel A. Total speculation R1 [based on (1-3) year portfolio delta]

\begin{tabular}{|c|c|c|c|c|c|c|c|c|c|c|c|}
\hline & I & II & III & IV & $\mathrm{V}$ & VI & VII & VIII & IX & $\mathrm{X}$ & XI \\
\hline \multirow{2}{*}{ Firm size } & $-0.006 * * *$ & $-0.005 * * *$ & $-0.005 * * *$ & & $-0.004 * * *$ & & $-0.004 * *$ & & -0.003 & & $-0.004 * *$ \\
\hline & $(-4.39)$ & $(-3.06)$ & $(-2.77)$ & & $(-3.06)$ & & $(-2.53)$ & & $(-1.58)$ & & $(-2.41)$ \\
\hline \multirow{2}{*}{$Z$ score } & & $-0.003^{*}$ & $-0.008^{*}$ & & & & & & & & \\
\hline & & $(-1.90)$ & $(-1.65)$ & & & & & & & & \\
\hline \multirow{2}{*}{$Z$ score 2} & & & 0.001 & & & & & & & & \\
\hline & & & (1.16) & & & & & & & & \\
\hline \multirow{2}{*}{$\begin{array}{l}\text { Log (delta of CEO } \\
\text { compensation) }\end{array}$} & & & & $-0.002 * *$ & -0.001 & & & & & & \\
\hline & & & & $(-2.04)$ & $(-0.65)$ & & & & & & \\
\hline \multirow{2}{*}{$\begin{array}{l}\text { Log (vega of CEO } \\
\text { compensation) }\end{array}$} & & & & & & $-0.002 * * *$ & $-0.002 * *$ & & & & \\
\hline & & & & & & $(-3.00)$ & $(-2.00)$ & & & & \\
\hline \multirow{2}{*}{$\begin{array}{l}\log \text { (delta of CFO } \\
\text { compensation) }\end{array}$} & & & & & & & & $-0.002 *$ & -0.001 & & \\
\hline & & & & & & & & $(-1.86)$ & $(-1.38)$ & & \\
\hline \multirow{2}{*}{$\begin{array}{l}\text { Log (vega of CFO } \\
\text { compensation) }\end{array}$} & & & & & & & & & & $-0.002 * *$ & -0.001 \\
\hline & & & & & & & & & & $(-2.01)$ & $(-1.12)$ \\
\hline \multirow{2}{*}{$\begin{array}{l}\text { Inverse Mills } \\
\text { Ratio }\end{array}$} & -0.000 & 0.002 & 0.001 & -0.001 & -0.011 & -0.004 & $-0.013^{*}$ & 0.001 & -0.011 & -0.002 & -0.010 \\
\hline & $(-0.02)$ & $(0.23)$ & $(0.10)$ & $(-0.12)$ & $(-1.59)$ & $(-0.64)$ & $(-1.84)$ & $(0.08)$ & $(-1.09)$ & $(-0.29)$ & $(-1.45)$ \\
\hline \multirow{2}{*}{ Intercept } & $0.063 * * *$ & $0.062 * * *$ & $0.064 * * *$ & $0.041 * * *$ & $0.060 * * *$ & $0.043 * * *$ & $0.064 * * *$ & $0.033 * * *$ & $0.060 * * *$ & $0.031 * * *$ & $0.054 * * *$ \\
\hline & $(5.27)$ & $(4.88)$ & $(5.02)$ & $(3.45)$ & $(4.49)$ & $(4.91)$ & $(5.30)$ & $(3.07)$ & $(2.96)$ & (3.97) & $(4.37)$ \\
\hline \multirow{3}{*}{$\begin{array}{l}\text { Observations } \\
\mathrm{X}^{2} \\
\operatorname{Pr}>\chi^{2}\end{array}$} & 276 & 235 & 235 & 178 & 178 & 183 & 183 & 90 & 90 & 128 & 128 \\
\hline & 57.51 & 63.05 & 64.54 & 4.172 & 59.60 & 8.976 & 62.91 & 3.443 & 27.31 & 4.048 & 46.60 \\
\hline & 0.0000 & 0.0000 & 0.0000 & 0.0411 & 0.0000 & 0.00274 & 0.0000 & 0.0635 & 0.0000 & 0.0442 & 0.0000 \\
\hline
\end{tabular}


Table 8 (contd.)

\begin{tabular}{|c|c|c|c|c|c|c|c|c|c|c|c|}
\hline & $\mathrm{I}$ & II & III & IV & $\mathrm{V}$ & $\mathrm{VI}$ & VII & VIII & IX & $\mathrm{X}$ & $\mathrm{XI}$ \\
\hline Firm size & $\begin{array}{c}-0.009 * * * \\
(-4.21)\end{array}$ & $\begin{array}{c}-0.007 * * * \\
(-2.73)\end{array}$ & $\begin{array}{c}-0.005 * * \\
(-2.16)\end{array}$ & & $\begin{array}{c}-0.007 * * * \\
(-2.75)\end{array}$ & & $\begin{array}{c}-0.007 * * * \\
(-2.71)\end{array}$ & & $\begin{array}{l}-0.006 \\
(-1.46)\end{array}$ & & $\begin{array}{c}-0.008 * * \\
(-2.51)\end{array}$ \\
\hline$Z$ score & & $\begin{array}{c}-0.006^{* * * *} \\
(-2.86)\end{array}$ & $\begin{array}{c}-0.024 * * * \\
(-3.47)\end{array}$ & & & & & & & & \\
\hline$Z$ score 2 & & & $\begin{array}{c}0.003 * * * \\
(2.76)\end{array}$ & & & & & & & & \\
\hline $\begin{array}{l}\mathrm{Log} \text { (delta of CEO } \\
\text { compensation) }\end{array}$ & & & & $\begin{array}{c}-0.005 * * \\
(-2.57)\end{array}$ & $\begin{array}{l}-0.002 \\
(-1.16)\end{array}$ & & & & & & \\
\hline $\begin{array}{l}\text { Log (vega of CEO } \\
\text { compensation) }\end{array}$ & & & & & & $\begin{array}{c}-0.004 * * * \\
(-2.68)\end{array}$ & $\begin{array}{l}-0.002 \\
(-1.59)\end{array}$ & & & & \\
\hline $\begin{array}{l}\mathrm{Log} \text { (delta of CFO } \\
\text { compensation) }\end{array}$ & & & & & & & & $\begin{array}{l}-0.002 \\
(-1.29)\end{array}$ & $\begin{array}{l}-0.001 \\
(-0.80)\end{array}$ & & \\
\hline $\begin{array}{l}\log \text { (vega of CFO } \\
\text { compensation) }\end{array}$ & & & & & & & & & & $\begin{array}{l}-0.002 \\
(-1.56)\end{array}$ & $\begin{array}{l}-0.001 \\
(-0.55)\end{array}$ \\
\hline $\begin{array}{l}\text { Inverse Mills } \\
\text { Ratio }\end{array}$ & $\begin{array}{l}-0.023 \\
(-1.60)\end{array}$ & $\begin{array}{l}-0.012 \\
(-0.76)\end{array}$ & $\begin{array}{l}-0.016 \\
(-1.08)\end{array}$ & $\begin{array}{l}-0.018 \\
(-1.64)\end{array}$ & $\begin{array}{c}-0.035 * * * \\
(-2.76)\end{array}$ & $\begin{array}{c}-0.018^{*} \\
(-1.69)\end{array}$ & $\begin{array}{c}-0.035 * * * \\
(-2.82)\end{array}$ & $\begin{array}{l}-0.006 \\
(-0.49)\end{array}$ & $\begin{array}{l}-0.026 \\
(-1.39)\end{array}$ & $\begin{array}{l}-0.017 \\
(-1.39)\end{array}$ & $\begin{array}{c}-0.035^{* *} \\
(-2.45)\end{array}$ \\
\hline Intercept & $\begin{array}{c}0.089 * * * \\
(5.45) \\
\end{array}$ & $\begin{array}{c}0.088 * * * \\
(5.02) \\
\end{array}$ & $\begin{array}{c}0.096 * * * \\
(5.43) \\
\end{array}$ & $\begin{array}{c}0.081 * * * \\
(3.87) \\
\end{array}$ & $\begin{array}{c}0.111 * * * \\
(4.59) \\
\end{array}$ & $\begin{array}{c}0.067 * * * \\
(4.47) \\
\end{array}$ & $\begin{array}{c}0.105^{* * *} \\
(5.02) \\
\end{array}$ & $\begin{array}{c}0.043 * * \\
(2.34) \\
\end{array}$ & $\begin{array}{c}0.087 * * \\
(2.44) \\
\end{array}$ & $\begin{array}{c}0.052 * * * \\
(3.51) \\
\end{array}$ & $\begin{array}{c}0.099 * * * \\
(4.06) \\
\end{array}$ \\
\hline $\begin{array}{l}\text { Observations } \\
\chi^{2}\end{array}$ & $\begin{array}{c}296 \\
53.82\end{array}$ & $\begin{array}{c}252 \\
66.00\end{array}$ & $\begin{array}{c}252 \\
74.16\end{array}$ & $\begin{array}{c}190 \\
6.627\end{array}$ & $\begin{array}{c}190 \\
56.56\end{array}$ & $\begin{array}{c}196 \\
7.178\end{array}$ & $\begin{array}{c}196 \\
58.67\end{array}$ & $\begin{array}{c}99 \\
1.661\end{array}$ & $\begin{array}{c}99 \\
22.56\end{array}$ & 2.446 & $\begin{array}{c}141 \\
42.28\end{array}$ \\
\hline $\operatorname{Pr}>\chi^{2}$ & 0.0000 & 0.0000 & 0.0000 & 0.0100 & 0.0000 & 0.00738 & 0.0000 & 0.198 & 0.0000 & 0.118 & 0.0000 \\
\hline
\end{tabular}


Table 9

\section{Speculation and Insider Ownership (OLS Regressions)}

This table presents the OLS regression results for speculation as a function of insider ownership. Total speculation is the standard deviation of the quarterly total hedge ratios and $x$-year speculation is the standard deviation of the quarterly $x$-year hedge ratios. Total speculation R1 is the standard deviation of the quarterly total hedge ratio defined as equal to [- Portfolio delta (1-3 year contracts)] / firm's gold reserves. Total speculation R2 is the standard deviation of the quarterly total hedge ratio defined as equal to [- Portfolio delta (1-5 year contracts)] / firm's gold reserves. For $x$-year speculation the sample is restricted to firms that hedge $x$ years ahead for $x=1,2$, and 3. For total speculation and total speculation R1, the sample is restricted to firms that hedge 1, 2, or 3 years ahead. For total speculation R2, the sample includes all firms that hedge 1, 2, 3, 4, or 5 years ahead. Insider ownership is the dollar value of insider stock holdings, where insiders include all executives and board directors. Figures in parentheses denote $t$-statistics based on clustered (by firm) standard errors. $*, * *$, and *** denote significance at the 10,5 , and $1 \%$ levels respectively.

\begin{tabular}{|c|c|c|c|c|c|c|}
\hline & I & II & III & IV & VII & VIII \\
\hline & $\begin{array}{c}\text { Total } \\
\text { speculation }\end{array}$ & $\begin{array}{c}\text { Total } \\
\text { speculation } \\
\text { R1 }\end{array}$ & $\begin{array}{c}\text { Total } \\
\text { speculation } \\
\text { R2 }\end{array}$ & $\begin{array}{c}\text { 1-Year } \\
\text { Speculation }\end{array}$ & $\begin{array}{c}\text { 2-Year } \\
\text { Speculation }\end{array}$ & $\begin{array}{c}\text { 3-Year } \\
\text { Speculation }\end{array}$ \\
\hline \multirow{2}{*}{$\begin{array}{l}\text { Log (insider } \\
\text { ownership) }\end{array}$} & $-0.006 * *$ & -0.001 & $-0.004 *$ & $-0.012 *$ & $-0.017 * * *$ & 0.003 \\
\hline & $(-2.16)$ & $(-1.40)$ & $(-2.00)$ & $(-1.98)$ & $(-3.09)$ & $(0.37)$ \\
\hline \multirow{2}{*}{ Intercept } & $0.174 * * *$ & $0.044 * *$ & $0.087 * *$ & $0.366^{* * *}$ & $0.406^{* * *}$ & 0.047 \\
\hline & $(3.62)$ & $(2.53)$ & $(2.71)$ & $(3.69)$ & $(4.00)$ & $(0.40)$ \\
\hline Observations & 85 & 134 & 145 & 149 & 110 & 92 \\
\hline R-squared & 0.04 & 0.02 & 0.03 & 0.05 & 0.04 & 0.00 \\
\hline
\end{tabular}


Table 10

Speculation and Insider Ownership (Heckman Two-step Regressions)

This table presents the regression results of the second step of a Heckman (1979) two-step selection model, which models speculation as a function of insider ownership. The first step models the decision to use derivatives. Total speculation is the standard deviation of the quarterly total hedge ratios and x-year speculation is the standard deviation of the quarterly $\mathrm{x}$-year hedge ratios. Total speculation R1 is the standard deviation of the quarterly total hedge ratio defined as equal to [- Portfolio delta (1-3 year contracts)] / firm's gold reserves. Total speculation R2 is the standard deviation of the quarterly total hedge ratio defined as equal to [- Portfolio delta (1-5 year contracts)] / firm's gold reserves. For X-year speculation the sample is restricted to firms that hedge $\mathrm{x}$ years ahead for $\mathrm{x}=1,2$, and 3. For total speculation and total speculation R1, the sample is restricted to firms that hedge 1 , 2 , or 3 years ahead. For total speculation R2, the sample includes all firms that hedge 1, 2, 3, 4, or 5 years ahead. Insider ownership is the dollar value of insider stock holdings, where insiders include all executives and board directors. Figures in parentheses denote $t$-statistics with robust standard errors. *,**, and *** denote significance at the 10,5 , and $1 \%$ levels respectively.

\begin{tabular}{|c|c|c|c|c|c|c|c|c|c|c|c|c|}
\hline & $\mathrm{I}$ & II & III & IV & $\mathrm{V}$ & VI & VII & VIII & IX & $\mathrm{X}$ & $\mathrm{XI}$ & XII \\
\hline & \multicolumn{2}{|c|}{ Total Speculation } & \multicolumn{2}{|c|}{ Total Speculation R1 } & \multicolumn{2}{|c|}{ Total Speculation R2 } & \multicolumn{2}{|c|}{ 1-Year Speculation } & \multicolumn{2}{|c|}{ 2-Year Speculation } & \multicolumn{2}{|c|}{ 3-Year Speculation } \\
\hline Firm size & & $\begin{array}{c}-0.017 * * * \\
(-2.67)\end{array}$ & & $\begin{array}{c}-0.004 * * \\
(-2.44)\end{array}$ & & $\begin{array}{l}-0.005 \\
(-1.58)\end{array}$ & & $\begin{array}{c}-0.019 * * \\
(-2.52)\end{array}$ & & $\begin{array}{c}-0.050 * * * \\
(-2.74)\end{array}$ & & $\begin{array}{l}-0.009 \\
(-1.02)\end{array}$ \\
\hline \multirow{2}{*}{$\begin{array}{l}\text { Log (insider } \\
\text { ownership) }\end{array}$} & $-0.006^{*}$ & -0.000 & -0.001 & 0.000 & $-0.004 * *$ & -0.002 & $-0.012 * * *$ & -0.006 & -0.016 & -0.004 & 0.000 & 0.003 \\
\hline & $(-1.83)$ & $(-0.08)$ & $(-1.35)$ & $(0.01)$ & $(-1.98)$ & $(-1.00)$ & $(-2.66)$ & $(-1.16)$ & $(-1.63)$ & $(-0.42)$ & $(0.01)$ & $(0.50)$ \\
\hline Inverse Mills & -0.023 & $-0.036^{*}$ & -0.002 & -0.006 & -0.012 & -0.018 & 0.003 & -0.021 & -0.001 & -0.080 & -0.043 & $-0.055^{*}$ \\
\hline Ratio & $(-1.14)$ & $(-1.81)$ & $(-0.25)$ & $(-0.90)$ & $(-1.06)$ & $(-1.48)$ & $(0.10)$ & $(-0.70)$ & $(-0.02)$ & $(-1.26)$ & $(-1.50)$ & $(-1.75)$ \\
\hline Intercept & $\begin{array}{c}0.187 * * * \\
(3.12)\end{array}$ & $\begin{array}{c}0.215^{* * *} \\
(3.62)\end{array}$ & $\begin{array}{c}0.042 * * \\
(2.45)\end{array}$ & $\begin{array}{c}0.046^{* * *} \\
(2.76)\end{array}$ & $\begin{array}{c}0.095^{* * *} \\
(2.88)\end{array}$ & $\begin{array}{c}0.100 * * * \\
(3.05)\end{array}$ & $\begin{array}{c}0.354 * * * \\
(4.57)\end{array}$ & $\begin{array}{c}0.387 * * * \\
(5.02)\end{array}$ & $\begin{array}{c}0.390 * * \\
(2.13)\end{array}$ & $\begin{array}{c}0.595 * * * \\
(3.07)\end{array}$ & $\begin{array}{l}0.130 \\
(1.35)\end{array}$ & $\begin{array}{l}0.160 \\
(1.57)\end{array}$ \\
\hline Observations & 82 & 82 & 124 & 124 & 132 & 132 & 136 & 136 & 101 & 101 & 88 & 88 \\
\hline$\chi^{2}$ & 3.355 & 58.42 & 1.811 & 52.03 & 3.920 & 49.95 & 7.053 & 59.27 & 2.657 & 63.85 & 0.000221 & 48.48 \\
\hline $\operatorname{Pr}>\chi^{2}$ & 0.0670 & 0.0000 & 0.178 & 0.0000 & 0.0477 & 0.0000 & 0.00791 & 0.0000 & 0.103 & 0.0000 & 0.988 & 0.0000 \\
\hline
\end{tabular}

